Review article

\title{
COPD phenotypes and machine learning cluster analysis: A systematic review and future research agenda
}

\author{
Vasilis Nikolaou $^{\text {a, , }}$, Sebastiano Massaro ${ }^{\text {a,b }}$, Masoud Fakhimi ${ }^{\text {a }}$, Lampros Stergioulas ${ }^{\text {a }}$, \\ David Price $^{\mathrm{c}}$ \\ ${ }^{\text {a }}$ Surrey Business School, University of Surrey, Guildford, GU2 7HX, UK \\ b The Organizational Neuroscience Laboratory, London, WC1N 3AX, UK \\ c Observational and Pragmatic Research Institute, Singapore, Singapore; Centre of Academic Primary Care, Division of Applied Health Sciences, University of Aberdeen, \\ Aberdeen, UK
}

\section{A R T I C L E I N F O}

\section{Keywords:}

Chronic respiratory disease

Subtypes

Statistical analysis

\begin{abstract}
A B S T R A C T
Chronic Obstructive Pulmonary Disease (COPD) is a highly heterogeneous condition projected to become the third leading cause of death worldwide by 2030. To better characterize this condition, clinicians have classified patients sharing certain symptomatic characteristics, such as symptom intensity and history of exacerbations, into distinct phenotypes. In recent years, the growing use of machine learning algorithms, and cluster analysis in particular, has promised to advance this classification through the integration of additional patient characteristics, including comorbidities, biomarkers, and genomic information. This combination would allow researchers to more reliably identify new COPD phenotypes, as well as better characterize existing ones, with the aim of improving diagnosis and developing novel treatments. Here, we systematically review the last decade of research progress, which uses cluster analysis to identify COPD phenotypes. Collectively, we provide a systematized account of the extant evidence, describe the strengths and weaknesses of the main methods used, identify gaps in the literature, and suggest recommendations for future research.
\end{abstract}

\section{Introduction}

Chronic Obstructive Pulmonary Disease (COPD) is a group of lung diseases, such as emphysema, chronic bronchitis, and asthma, that cause breathing difficulties due to inflammation of the lungs and narrowing of the airways. Typical symptoms of COPD include breathlessness, a persistent cough with phlegm, frequent chest infections, and wheezing. Its main causes are smoking, which accounts for almost $90 \%$ of cases, occupational exposure to dust and fumes, and air pollution [1]. COPD represents one of the most common respiratory diseases, and it is projected to become the third leading cause of death worldwide by 2030 [2], principally because of difficulties in early, accurate diagnosis.

To better characterize COPD and improve diagnosis, the extant research has identified different patient phenotypes (i.e., the common clinical characteristics shared by patients affected by COPD). These phenotypes are usually assessed through clinical examinations, generally following the recommendations provided by the Global Obstructive Lung Disease initiative (GOLD) [3]. Specifically, GOLD classifies COPD patients into four phenotype-like categories according to a $2 \times 2$ matrix structured along the dimensions of symptoms and history of exacerbations (Table 1).

Whilst beneficial in guiding clinical practice, this and other forms of COPD classification are often in need of stronger statistical support with respect to their predictive ability regarding clinically meaningful outcomes, such as mortality and response to treatment [4]. For instance, a large prospective study ( $\mathrm{n}=12,108$ patients) recently showed that COPD patients receiving maintenance therapy were similarly distributed across the four GOLD phenotypes when compared to patients who received a target treatment [5]. Likewise, the proportion of comorbidities and rate of exacerbations reported across the COPD groups were similar for both cohorts, suggesting a limited discriminatory ability of these phenotypes [5].

To address this issue, research has increasingly called for the integration of other determinants, such as physiological characteristics (e.g., age, body mass index, waist circumference) $[6-16,18]$, comorbidities (e. g., diabetes, cardiovascular diseases) $[6,8,10,13,16,17,19]$, pulmonary function tests [7,8,11-16,19], biomarkers [6,19], and genetic variants [7], as valuable information to facilitate a more comprehensive

\footnotetext{
* Corresponding author. University of Surrey, Surrey Business School, Alexander Fleming Rd, Guildford, GU2 7HX, UK.

E-mail address: v.nikolaou@surrey.ac.uk (V. Nikolaou).
} 
Table 1

2019 GOLD classification of COPD phenotypes.

\begin{tabular}{lll}
\hline & Symptoms & \\
\hline $\begin{array}{l}\text { Moderate/severe exacerbation } \\
\text { history }\end{array}$ & mMRC 0-1 and & mMRC $\geq 2$ and \\
$\begin{array}{l}\text { CAT } \text { or } \geq 1 \text { leading to hospital } \\
\text { admission }\end{array}$ & C & CAT $\geq 10$ \\
$\begin{array}{l}0 \text { or } 1 \text { not leading to hospital } \\
\text { admission }\end{array}$ & A & D \\
\hline
\end{tabular}

mMRC, modified Medical Research Council dyspnea questionnaire; CAT, COPD assessment test.

characterization of the distinctive biological nature of COPD phenotypes, thereby promising to improve their predictive ability for clinically relevant outcomes. In particular, with sustained progress in applying machine learning algorithms to medicine, research has recently begun to put forward the powerful method of clustering - a machine learning method, which allows researchers to find structures in the data so that the elements of the same cluster (i.e., a phenotype) are more similar to each other than to those from different clusters [20], with the aim of integrating patients' information and identifying patterns of association that can characterize COPD phenotypes more precisely.

Yet, at present, there is still little evidence-based information available that both systematizes current knowledge on cluster analysis for COPD phenotype characterization and pinpoints the core benefits and limitations of the different approaches. Here, we aim to tackle this gap by reviewing the last decade of research, which uses cluster analysis to identify clinically meaningful COPD phenotypes. In the following sections of this article we describe our search strategy, synthetize the characteristics of the articles retrieved (e.g., study design, population, phenotypes' features), and provide recommendations aimed at improving the use and performance of these methods in future research and clinical practice.

\subsection{Search strategy and selection criteria}

In keeping with PRISMA guidelines, we conducted our search through a systematic consultation of the Medline PubMed, Cochrane Library, Scopus, and Web of Science (Fig. 1) databases.

We also hand-searched the reference lists of the retrieved articles. Additionally, we searched articles in leading pulmonary and respiratory medicine scholarly outlets to specifically include journals such as The Lancet Respiratory Medicine and The American Journal of Respiratory and Critical Care Medicine, among others.

Briefly, we tailored the search to probe for overarching concepts and relations pertaining to the domains of machine learning and COPD phenotypes. Specifically, we searched for studies that used cluster analysis to identify COPD phenotypes by using the MeSH keywords "COPD", "phenotypes", "cluster analysis", "clustering" and "machine learning" as well as their possible variants and combinations. Moreover, we aimed to search for articles in which the COPD phenotypes reported were validated by clinically meaningful outcomes, eg, mortality, exacerbations, and response to therapy. We also searched for ongoing registered studies relevant to our research question, including NOVELTY [21], SPIROMICS [22] and the BigCOPData [23] project, which, whilst informative to the overall picture, were not individually retained in our analysis because their final results have yet to be fully disclosed.

Our search resulted in 117 articles published mainly in English and covering the period between 2003 and 2019. After excluding duplicates, we screened 113 papers to select unambiguous publications of relevant research. Hereby, 65 articles were excluded because they were not relevant to COPD phenotypes and/or machine learning methods, while
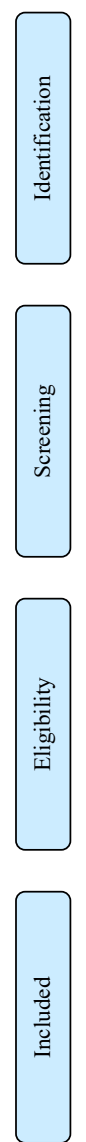

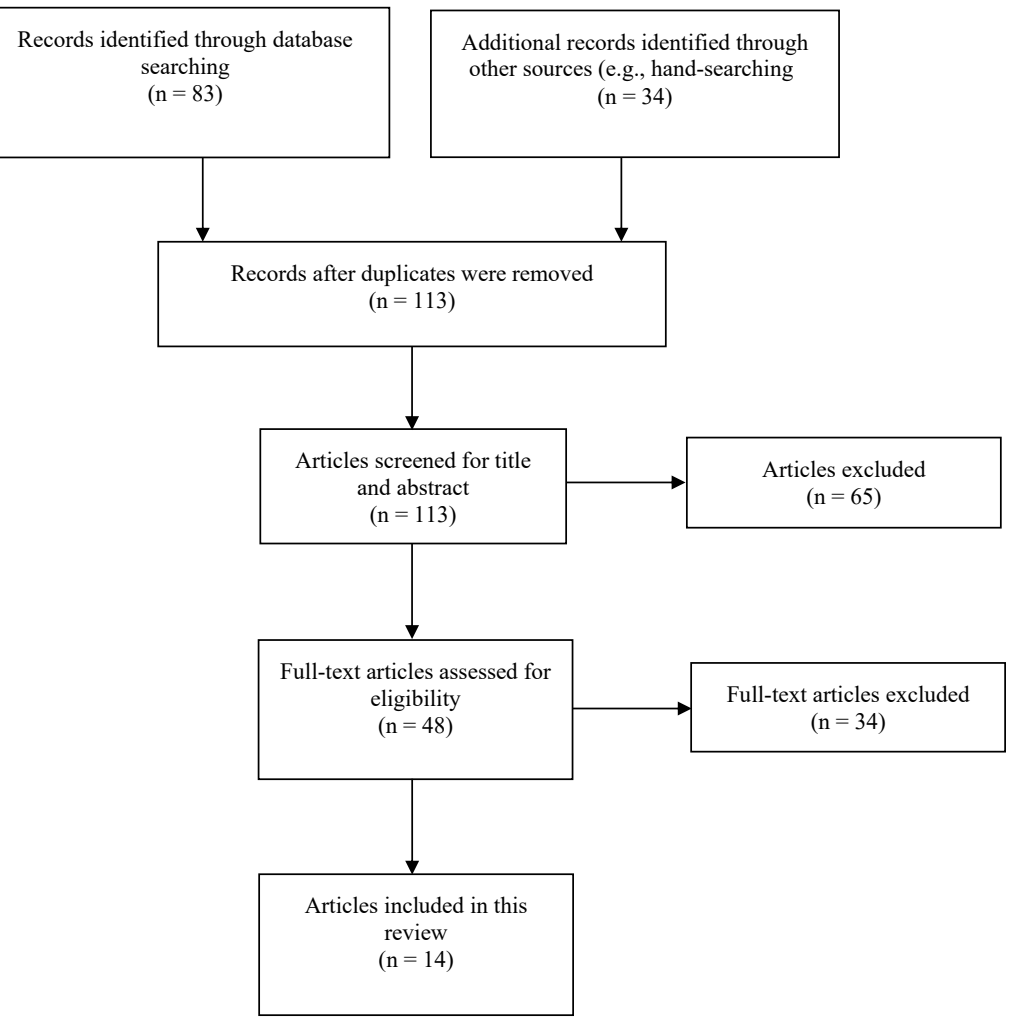

Fig. 1. PRISMA diagram for the systematic review. 
34 studies were excluded because the COPD phenotypes reported had not been validated with clinically meaningful outcomes.

Fourteen studies that satisfied our inclusion/exclusion criteria were retained in this review. Next, we present the entire body of retrieved studies, focusing in particular on the population characteristics, study design, sample size, the derived COPD phenotypes, and the clinical outcomes against which the phenotypes were validated of the articles respecting our inclusion criteria (Table 2). Moreover, we highlighted important inputs that we appreciated from the studies excluded from our systematic analysis, as well as specific phenotypes observed in the Evaluation of COPD Longitudinally to Identify Predictive Surrogate Endpoints (ECLIPSE) [24] study.

\section{Findings}

\subsection{Studies respecting inclusion criteria for review}

\subsubsection{Populations}

The sample size varied considerably across studies, spanning from 65 [18] to 30,961 patients [6].The majority of the retrieved works involved multi-centre, observational cross-sectional cohorts across the world (e. g., Italy, France, Spain, Belgium, United Kingdom, Korea, Japan, New Zealand, China). Data were collected from university hospitals, tertiary care, and pulmonary rehabilitation settings. This variability may explain the high variation in sample sizes. For instance, the largest study [6] (ie, CALIBER) covered a longitudinal cohort for a period of 18 years. This cohort comprised the data of electronic health records from three UK national resources: the Clinical Practice Research Datalink (CPRD), the Hospital Episode Statistics (HES), and information on cause-specific mortality from the Office for National Statistics (ONS). The second largest study [7] was based on the Genetic Epidemiology of COPD (COPDGene) and aimed to investigate the genetic factors responsible for COPD development. Moreover, similar to CALIBER [6], Burgel et al. [8] combined three national COPD cohorts from France and Belgium as well as one independent cohort from the COPD Cohorts Collaborative International Assessment (3CIA) initiative. Two other relatively large studies, each with over 1000 patients, were carried out in Asia. One was based on the Korean COPD subgroup multi-centre cohort [9] and the other one [10] included out-patients of universities' pulmonary clinics and referral hospitals in 13 Asian cities.

Importantly, despite the diverse ethnic backgrounds of the populations of these studies, the identified COPD phenotypes were rather consistent across studies, including elements of asthma-COPD overlaps, comorbidities, and obesity, amongst others.

\subsection{Clinical outcomes}

A core characteristic shared among the reviewed studies is that all COPD phenotypes were validated by clinically meaningful outcomes, such as exacerbations, health-related quality of life, mortality rate, and responses to therapy. These phenotypes were cross-validated in a large ( $n=2746)$ three-year observational multi-centre international study the Evaluation of COPD Longitudinally to Identify Predictive Surrogate End-points (ECLIPSE) [24]. In this study, a cross-sectional analysis of the baseline data showed that patients with COPD had more frequent comorbidities, especially cardiovascular ones, when compared to controls [25]. It also showed that males with COPD were more susceptible to cardiovascular comorbidity than females; moreover, in Pikoula et al. [6], patients with comorbid cardiovascular disease and diabetes were characterized by high hospital admission rates for acute exacerbations of COPD (AECOPD) and were reported as being more likely to die of cardiovascular disease.

Building on these results, subsequent works $[26,27]$ identified phenotypes of patients with frequent (i.e., two or more per year) exacerbations as well as patients with a rapid decline in their lung function. The latter evidence [27] was further extended by a five-year longitudinal study that classified patients into three groups: fast decline, slow decline, and stable patterns [28]. The latter work showed that the only factor significantly associated with a fast decline of FEV1 (Forced Expiratory Volume in $1 \mathrm{~s}$ ) was the severity of the emphysema. Moreover, $25 \%$ of the cohort was represented by the so-called "asthma-COPD overlap," or ACO, in which patients are characterized by having more exacerbations and more frequent comorbidities than in other rapid-decline COPD types [29].

\subsection{Features of COPD phenotypes}

We found substantial heterogeneity in both the numbers and features of phenotypes presented in the literature. The number of COPD phenotypes identified varied from two to five, the most frequently reported being three [10,11,13-15] and five [6,8,16,17,19].

Intriguingly, the features pertaining to the three most reported phenotypes varied across studies. For instance, phenotypes were characterized by patients having frequent exacerbations and a fast decline in lung function and in quality of life [10], but also by patients of a young age with fewer symptoms and exacerbations [11], or patients with severe respiratory disease but a low rate of comorbidities and older patients with a high rate of comorbidities (e.g., cardiovascular diseases and diabetes) but lower airway limitation and less obesity $[12,13]$.

Two studies [14,15] reported similar phenotypes with respect to COPD severity. Peters et al. [14] identified three phenotypes in which patients were characterized by moderate COPD and a low impact on overall health status, moderate COPD with a high impact on health status, or severe COPD with a moderate impact on health status. Similarly, the three phenotypes identified by Garcia-Aymerich et al. [15] were characterized by moderate, severe, and systemic COPD; the latter phenotype also had a high rate of cardiovascular comorbidities.

When four phenotypes were reported, they also differed in terms of the severity of symptoms. Specifically, Yoon et al. [9] clustered patients both according to their COPD severity (ie, mild, moderate, severe) and by identifying the ACO phenotype. A related work [7] classified patients according to the severity of emphysema (i.e., minimal, moderate, severe). Moreover, two studies [12,13] emphasized the distinction of two key population groups: a younger group of patients with moderate to severe respiratory disease but few comorbidities, and an older group with mild to severe airflow limitations but a high rate of cardiovascular comorbidities.

In those articles that identified five phenotypes, the reported features were more homogeneous than those identified in studies reporting fewer phenotypes. For instance, almost every study reported similar comorbidities, namely cardiovascular and metabolic diseases (e.g., diabetes), obesity, and ACO, as possible confounding factors. In Burgel et al. [8], the derived phenotypes confirmed other existing findings [12,13], suggesting the identification of an older group of patients with a high rate of cardiovascular comorbidities and diabetes but with less severe respiratory impairments. Similarly, Chen et al. [16] acknowledged a group of young patients with mild airflow obstructions, few symptoms, and infrequent severe exacerbations vis-à-vis older patients with more symptoms, frequent severe exacerbations, and a high mortality rate.

Overall, the diversity of phenotypes and populations presented in the current literature should not be surprising. Indeed, as we explain in the following, this scenario is largely due to an overarching limited reliance on statistical support in validating COPD with clinically meaningful outputs. Confirming our argument, for instance, a large study [30] carried out across ten independent cohorts from different populations in North America and Europe clearly showed that when identical methods were implemented for 17,146 individuals with COPD using common COPD-related characteristics, the reproducibility of COPD phenotypes across studies was rather modest. 
Table 2

Summary of studies using clustering analysis to identify COPD phenotypes used in the systematic analysis.

\begin{tabular}{|c|c|c|c|c|c|}
\hline $\begin{array}{l}\text { First author } \\
\text { and year of } \\
\text { publication }\end{array}$ & $\begin{array}{l}\text { Sample size (i.e., } \\
\text { number of } \\
\text { patients) } \\
\text { contributing to } \\
\text { cluster analysis }\end{array}$ & Name of cohort and study design & $\begin{array}{l}\text { Population characteristics and } \\
\text { setting(s) }\end{array}$ & COPD phenotypes identified & $\begin{array}{l}\text { Clinical outcome(s) used } \\
\text { for validation }\end{array}$ \\
\hline $\begin{array}{l}\text { Yoon et al. } \\
\text { (2019) [9] }\end{array}$ & 1195 & $\begin{array}{l}\text { Korea COPD subgroup study } \\
\text { (KOCOSS), retrospective } \\
\text { observational multi-centre } \\
\text { longitudinal cohort }\end{array}$ & $\begin{array}{l}\text { Patients with COPD evaluated } \\
\text { at } 6 \text {-month intervals by } \\
\text { experienced pulmonologists at } \\
\text { university hospitals }\end{array}$ & $\begin{array}{l}\text { 1. Putative asthma-COPD overlap } \\
\text { 2. Mild COPD } \\
\text { 3. Moderate COPD } \\
\text { 4. Severe COPD }\end{array}$ & Acute exacerbation \\
\hline $\begin{array}{l}\text { Pikoula et al. } \\
\text { (2019) [6] }\end{array}$ & 30,961 & $\begin{array}{l}\text { CALIBER }^{\mathrm{a}} \text {, observational } \\
\text { prospective longitudinal cohort }\end{array}$ & $\begin{array}{l}\text { Patients who a) were } 35 \text { years } \\
\text { or older, b) had been registered } \\
\text { for at least one year in primary } \\
\text { care practice, c) had at least one } \\
\text { diagnostic code of COPD }\end{array}$ & $\begin{array}{l}\text { 1. Anxiety/depression } \\
\text { 2. Severe airflow obstruction and } \\
\text { frailty } \\
\text { 3. Cardiovascular disease and } \\
\text { diabetes } \\
\text { 4. Obesity/atopy } \\
\text { 5. Low prevalence of } \\
\text { comorbidities }\end{array}$ & $\begin{array}{l}\text { Rate of severe or moderate } \\
\text { acute COPD } \\
\text { exacerbations, respiratory } \\
\text { and cardiovascular related } \\
\text { mortality }\end{array}$ \\
\hline $\begin{array}{l}\text { Kim et al. } \\
\text { (2018) [10] }\end{array}$ & 1676 & $\begin{array}{l}\text { The Asian Network for Obstructive } \\
\text { Lung Disease (ANOLD) } \\
\text { international multi-centre } \\
\text { observational cross-sectional } \\
\text { prospective cohort }\end{array}$ & $\begin{array}{l}\text { Patients of Asian ethnicity, over } \\
40 \text { years old with FEV1/FVC }< \\
0.7 \text { assessed at pulmonary } \\
\text { clinics }\end{array}$ & $\begin{array}{l}\text { 1. Worse lung function but fewer } \\
\text { symptoms } \\
\text { 2. Worse lung function with more } \\
\text { symptoms and most frequent } \\
\text { exacerbations, faster FEV1 } \\
\text { decline and greatest SGRQ } \\
\text { decline } \\
\text { 3. Mild severity but higher BMI }\end{array}$ & $\begin{array}{l}\text { Exacerbations and quality } \\
\text { of life }\end{array}$ \\
\hline $\begin{array}{l}\text { Kim et al. } \\
\text { (2017) [11] }\end{array}$ & 272 & $\begin{array}{l}\text { COPD in dusty areas (CODA) } \\
\text { observational longitudinal } \\
\text { prospective cohort }\end{array}$ & $\begin{array}{l}\text { Patients over } 40 \text { years old with } \\
\text { FEV1/FVC }<0.7 \text { living near } \\
\text { cement plants who were } \\
\text { evaluated at enrolment and at a } \\
\text { 1-year follow-up at university } \\
\text { hospitals }\end{array}$ & $\begin{array}{l}\text { 1. Younger patients with fewer } \\
\text { symptoms and exacerbations } \\
\text { and mild airflow obstruction } \\
\text { 2. Patients with additional } \\
\text { symptoms and moderate } \\
\text { airflow obstruction and more } \\
\text { exacerbations requiring } \\
\text { hospitalization } \\
\text { 3. More female patients, } \\
\text { additional symptoms and mild } \\
\text { airflow obstruction and modest } \\
\text { frequency of exacerbations } \\
\text { requiring hospitalization }\end{array}$ & $\begin{array}{l}\text { Exacerbations and quality } \\
\text { of life }\end{array}$ \\
\hline $\begin{array}{l}\text { Burgel et al. } \\
\text { (2017) [8] }\end{array}$ & 2409 & $\begin{array}{l}\text { Three French/Belgian COPD } \\
\text { cohorts: a) the initiatives BPCO } \\
\text { observational multi-centre } \\
\text { prospective cross-sectional cohort, } \\
\text { b) the CPHG } \text { prospective }^{\mathrm{b}} \text { observational cohort, c) the } \\
\text { Leuven observational cross- } \\
\text { sectional cohort. An independent } \\
\text { cohort (the 3CIA }{ }^{\mathrm{c}} \text { initiative) was } \\
\text { also used for validation. }\end{array}$ & $\begin{array}{l}\text { Patients with stable COPD } \\
\text { assessed at university hospitals }\end{array}$ & $\begin{array}{l}\text { 1. Older patients with high rates } \\
\text { of cardiovascular comorbidities } \\
\text { and diabetes, but less severe } \\
\text { respiratory disease } \\
\text { 2. Moderate to severe respiratory } \\
\text { disease and low rate of } \\
\text { comorbidities } \\
\text { 3. Older patients with high } \\
\text { prevalence of comorbidities } \\
\text { and obesity } \\
\text { 4. Very severe respiratory disease } \\
\text { with low rates of cardiovascular } \\
\text { comorbidities and diabetes } \\
\text { 5. Mild respiratory disease and } \\
\text { low rates of comorbidities }\end{array}$ & 3-year all-cause mortality \\
\hline $\begin{array}{l}\text { Peters et al. } \\
\text { (2017) [14] }\end{array}$ & 619 & $\begin{array}{l}\text { Two interventional cohorts: a) } 1 \text { - } \\
\text { year follow-up treatment as usual } \\
\text { (TAU), b) 12-week pulmonary } \\
\text { rehabilitation (PR) program }\end{array}$ & $\begin{array}{l}\text { Two groups of patients: } 160 \text { out- } \\
\text { patients with COPD treated as } \\
\text { usual (TAU) and } 459 \text { patients } \\
\text { with pulmonary rehabilitation } \\
\text { (PR) at a university medical } \\
\text { centre }\end{array}$ & $\begin{array}{l}\text { 1. Moderate COPD, low impact on } \\
\text { health status (adaptive } \\
\text { phenotype) } \\
\text { 2. Severe COPD, moderate impact } \\
\text { on health status (adaptive) } \\
\text { 3. Moderate COPD, high impact } \\
\text { on health status (non-adaptive) }\end{array}$ & $\begin{array}{l}\text { Response to treatment } \\
\text { (TAU vs PR) }\end{array}$ \\
\hline $\begin{array}{l}\text { Chubachi } \\
\text { et al. } \\
\text { (2016) [17] }\end{array}$ & 311 & $\begin{array}{l}\text { The Keio COPD Comorbidity } \\
\text { Research (K-CCR) observational, } \\
\text { prospective cohort }\end{array}$ & $\begin{array}{l}\text { COPD patients with complete } \\
\text { comorbidities data with a 2- } \\
\text { year follow-up assessed at Keio } \\
\text { University and its affiliated } \\
\text { hospitals }\end{array}$ & $\begin{array}{l}\text { 1. Less comorbidity } \\
\text { 2. Malignancy } \\
\text { 3. Metabolic and cardiovascular } \\
\text { 4. Gastroesophageal reflux } \\
\text { disease (GERD) and } \\
\text { psychological } \\
\text { 5. Underweight and anaemic }\end{array}$ & $\begin{array}{l}\text { Health-related quality of } \\
\text { life (e.g. SGRQ, CAT, SF- } \\
\text { 36) }\end{array}$ \\
\hline $\begin{array}{l}\text { Fingleton } \\
\text { et al. } \\
\text { (2015) [19] }\end{array}$ & 389 & $\begin{array}{l}\text { A 3-phase cross-sectional study; } \\
\text { phase } 1 \text { (sample selection), phase } \\
2 \text { (phenotyping), phase } 3 \\
\text { (interventional study to assess } \\
\text { treatment responsiveness) }\end{array}$ & $\begin{array}{l}\text { Patients with symptoms of } \\
\text { wheezing and breathlessness in } \\
\text { the last } 12 \text { months who } \\
\text { completed phase } 2 \text { with no } \\
\text { missing data }\end{array}$ & $\begin{array}{l}\text { 1. Moderate to severe atopic } \\
\text { asthma } \\
\text { 2. Asthma-COPD overlap } \\
\text { 3. Obese/comorbid } \\
\text { 4. Mild atopic asthma } \\
\text { 5. Mild intermittent }\end{array}$ & $\begin{array}{l}\text { Response to treatment } \\
\text { (inhaled } \beta \text {-agonist, } \\
\text { antimuscarinic, } \\
\text { corticosteroid) }\end{array}$ \\
\hline $\begin{array}{l}\text { Chen et al. } \\
\text { (2014) [16] }\end{array}$ & 332 & $\begin{array}{l}\text { Observational prospective } \\
\text { longitudinal cohort }\end{array}$ & $\begin{array}{l}\text { Men with COPD diagnosed at } \\
\text { university hospital }\end{array}$ & $\begin{array}{l}\text { 1. Young patients with mild } \\
\text { airflow obstruction, few }\end{array}$ & Mortality \\
\hline
\end{tabular}


Table 2 (continued)

\begin{tabular}{|c|c|c|c|c|c|}
\hline $\begin{array}{l}\text { First author } \\
\text { and year of } \\
\text { publication }\end{array}$ & $\begin{array}{l}\text { Sample size (i.e., } \\
\text { number of } \\
\text { patients) } \\
\text { contributing to } \\
\text { cluster analysis }\end{array}$ & Name of cohort and study design & $\begin{array}{l}\text { Population characteristics and } \\
\text { setting(s) }\end{array}$ & COPD phenotypes identified & $\begin{array}{l}\text { Clinical outcome(s) used } \\
\text { for validation }\end{array}$ \\
\hline & & & & $\begin{array}{l}\text { symptoms and infrequent } \\
\text { severe exacerbations } \\
\text { 2. Older patients with mild } \\
\text { airflow obstruction, few } \\
\text { symptoms, infrequent severe } \\
\text { exacerbations but higher } \\
\text { mortality } \\
\text { 3. Older patients with moderate } \\
\text { respiratory disease, dyspnoea, } \\
\text { history of severe exacerbations } \\
\text { and underweight } \\
\text { 4. Patients with severe airflow } \\
\text { obstruction, many symptoms } \\
\text { and infrequent severe } \\
\text { exacerbations } \\
\text { 5. Patients with severe airflow } \\
\text { obstruction, many symptoms } \\
\text { and frequent severe } \\
\text { exacerbations and high } \\
\text { mortality }\end{array}$ & \\
\hline $\begin{array}{l}\text { Castaldi et al. } \\
\text { (2014) [7] }\end{array}$ & 8288 & $\begin{array}{l}\text { The Genetic Epidemiology of } \\
\text { COPD (COPDGene) study } \\
\text { observational cross-sectional } \\
\text { prospective cohort }\end{array}$ & $\begin{array}{l}\text { Former and current smokers } \\
\text { with or without COPD }\end{array}$ & $\begin{array}{l}\text { 1. No/mild obstruction and } \\
\text { minimal emphysema } \\
\text { 2. Mild upper zone emphysema } \\
\text { predominant } \\
\text { 3. Airway disease predominant } \\
\text { 4. Severe emphysema }\end{array}$ & $\begin{array}{l}\text { Exacerbations, dyspnoea, } \\
\text { COPD-associated genetic } \\
\text { variants }\end{array}$ \\
\hline $\begin{array}{l}\text { Altenburg } \\
\text { et al. } \\
\text { (2012) [18] }\end{array}$ & 65 & $\begin{array}{l}\text { An interventional prospective } \\
\text { cohort }\end{array}$ & $\begin{array}{l}\text { Patients with COPD } \\
\text { participating in a pulmonary } \\
\text { rehabilitation (PR) program at a } \\
\text { university medical centre }\end{array}$ & $\begin{array}{l}\text { 1. Worse lung function, } \\
\text { quadriceps force but better } \\
\text { response to exercise training } \\
\text { 2. Better lung function and } \\
\text { exercise capacity but less } \\
\text { response to exercise training }\end{array}$ & $\begin{array}{l}\text { Improvement in exercise } \\
\text { capacity }\end{array}$ \\
\hline $\begin{array}{l}\text { Burgel et al. } \\
\text { (2010) [12] }\end{array}$ & 322 & $\begin{array}{l}\text { The initiatives BPCO } \\
\text { observational multi-centre } \\
\text { prospective cross-sectional cohort }\end{array}$ & $\begin{array}{l}\text { Patients with stable COPD } \\
\text { assessed at } 17 \text { pulmonary units } \\
\text { in university hospitals }\end{array}$ & $\begin{array}{l}\text { 1. Young patients with severe } \\
\text { respiratory disease } \\
\text { 2. Older patients with mild } \\
\text { airflow limitation and mild } \\
\text { comorbidities } \\
\text { 3. Young patients with moderate } \\
\text { to severe airflow limitation, few } \\
\text { comorbidities } \\
\text { 4. Older patients with moderate to } \\
\text { severe airflow limitation and } \\
\text { high prevalence of } \\
\text { cardiovascular comorbidities }\end{array}$ & All-cause mortality \\
\hline $\begin{array}{l}\text { Burgel et al. } \\
\text { (2012) [13] }\end{array}$ & 527 & $\begin{array}{l}\text { Two cohorts: the Leuven } \\
\text { observational cross-sectional } \\
\text { cohort ( } 374 \text { patients) and the } \\
\text { NELSON randomized lung cancer } \\
\text { screening study (153 patients) }\end{array}$ & $\begin{array}{l}\text { Stable COPD patients assessed } \\
\text { at university hospitals' COPD } \\
\text { outpatient clinics }\end{array}$ & $\begin{array}{l}\text { 1. Young patients with severe } \\
\text { respiratory disease and low } \\
\text { prevalence of cardiovascular } \\
\text { comorbidities } \\
\text { 2. Older patients with less severe } \\
\text { airflow limitation, obese, high } \\
\text { prevalence of diabetes and } \\
\text { cardiovascular comorbidities } \\
\text { 3. Mild to moderate airflow } \\
\text { limitation, absent or mild } \\
\text { emphysema and dyspnoea, } \\
\text { normal nutritional status, } \\
\text { limited comorbidities }\end{array}$ & All-cause mortality \\
\hline $\begin{array}{l}\text { Garcia- } \\
\text { Aymerich } \\
\text { et al. } \\
\text { (2011) [15] }\end{array}$ & 342 & $\begin{array}{l}\text { An observational, prospective } \\
\text { cross-sectional cohort }\end{array}$ & $\begin{array}{l}\text { COPD patients hospitalized due } \\
\text { to COPD exacerbation in } \\
\text { teaching hospitals }\end{array}$ & $\begin{array}{l}\text { 1. Severe respiratory COPD } \\
\text { 2. Moderate respiratory COPD } \\
\text { 3. Systemic COPD (high } \\
\text { prevalence of cardiovascular } \\
\text { comorbidities) }\end{array}$ & $\begin{array}{l}\text { Hospitalizations and all- } \\
\text { cause mortality }\end{array}$ \\
\hline
\end{tabular}

${ }^{a}$ CALIBER: A database of electronic health records from three national sources; The Clinical Practice Research Datalink (CPRD), Hospital Episode Statistics (HES), and cause-specific mortality from the Office for National Statistics (ONS).

${ }^{\mathrm{b}}$ CPHG: The French College of General Hospital Respiratory Physicians.

c 3CIA: COPD Cohorts Collaborative International Assessment. 


\subsection{Studies excluded from the systematic analysis}

Ninety-nine studies were excluded either because a) they were irrelevant to COPD phenotypes or machine learning methods under study or b) the reported COPD phenotypes were not validated against clinical meaningful outcomes (Table 3).

Twenty one of those studies identified between two [31] and nine [32] phenotypes; however the number of phenotypes most frequently reported were either three [33-36], four [37-44] or five [45-51]. The works were predominantly observational - 12 were cross-sectional [31, $33,36,38-42,47-49,51]$, six prospective [34,43-46,50], two retrospective $[32,37]$ and one randomised placebo controlled clinical trial [35]. Reported samples were comprised between 75 [36] and 3144 [32] patients. In these studies, there was a remarkable heterogeneity among the reported phenotypes. For instance, when three phenotypes were reported, patients were characterized as either being young with few symptoms and mild airway limitation, or older and highly symptomatic with severe airway limitation or as a combination of both [34]. Moreover, de Torres et al. [34] showed that these phenotypes remained stable in most of the patients over a two years follow-up period.

In studies with four phenotypes patients were characterized by the severity of the disease, i.e., patients with mild to moderate disease, moderate to severe emphysema, mild to increased dyspnoea, low to high exacerbation risk or even an overlap of asthma and COPD [38,39,41]. In one of these studies, Bafadhel et al. [43] classified patients into four biologic clusters: a) bacterial-predominant, b) viral-predominant, c) eosinophilic-predominant and d) patients with limited changes in their inflammatory profile.

In clusters of five phenotypes patients were characterized not only by the severity of the disease $[45,48]$ but also by the presence of comorbidities [46] as well the asthma and COPD overlap syndrome [47-49]. We also observed a reported distinction between female patients with high body mass index, asthma, COPD, and symptom scores but no inflammation, and male patients with asthma and COPD with high eosinophil counts and low use of oral corticosteroids [47]. Another salient difference was shown between younger-onset asthma patients with severe symptoms and elderly patients with high frequency of comorbidities and concomitant COPD [50].

A list of commonly occurring COPD phenotypes, along with their grouping, is presented in Table 4; it summarizes the most frequently reported phenotypes among the studies we reviewed.

\section{Methods}

\subsection{Study design}

Generally speaking, the retrieved research based on observational studies [6-8] highlights the advantage of capturing large cohorts of patients with COPD as well as the opportunity to showcase "real-life" outputs from clinical practice. Moreover, and in contrast to controlled experiments such as clinical trials in which patients are selected homogeneously to satisfy certain inclusion and exclusion criteria, an observational study allows researchers to appreciate the patients' heterogeneity, which is a defining feature of COPD. Hence, the analysis of and outputs from such studies advance knowledge with respect to sample representativeness, covering actual COPD populations from different geographical settings.

On the other hand, the results coming from observational studies may lead to the emergence of unstable phenotypes, in turn making treatment decisions more complex. Similarly, because observational studies are generally carried out in university hospitals, tertiary care centres or rehabilitation settings, they tend to cover only severe COPD patients and may not be fully representative of the wider COPD population.

\subsection{Validation}

Across the reviewed studies, we acknowledge that the derived COPD phenotypes were often validated both internally (i.e., from the same population in terms of clinically meaningful outcomes such as exacerbations, mortality, and response to therapy) and externally on a different population (e.g., including the rapid lung function decline or the asthma-COPD overlap phenotype in the ECLIPSE cohort). This procedure offers strong reliability as it provides evidence for the generalizability and robustness of the results.

\subsection{Data reduction and clustering}

Most of all, from our analysis of the literature, we can appreciate the recurrent use of statistical techniques aiming to reduce the size of the data and group patients with similar characteristics into distinct clusters. These approaches have the immediate advantage of utilizing all available information, yet in practice they "operationalize" phenotypes as if they were mathematical constructs and as a result they may not always be closely relevant to the medical condition.

As such, issues such as the handling of missing data or the choice of variables feeding the analysis become paramount features to ensure the consistency of phenotype identification in progressing with COPD research. For instance, while the analysis of common features already offers a moderate concordance in determining COPD phenotypes [30], their robustness and reproducibility using an extended or diverse list of variables remains to be determined.

We argue that one of the first steps needed to overcome the issue of ensuring the reproducibility and alignment of COPD phenotypes is situated, at least to some extent, in the variety of statistical methods used to derive them (Table 5).

Most of the reviewed literature used data reduction methods to select the variables to include in the cluster analysis $[6-8,10-13,16]$. These methods vary from Principal Components Analysis (PCA) [52] to Multiple Correspondence Analysis (MCA) [53] - a method similar to PCA yet using categorical data - and factor analysis. PCA, MCA, and factor analysis $[54,55]$ share the characteristic that they reduce data dimensionality to identify a small number of clinically relevant variables able to explain most of the variations occurring in COPD patients' data. Whilst these approaches are beneficial to summarize data with a few variables without losing information, the interpretation of the derived variables within a clinical context is rarely straightforward due to their intimate mathematical nature.

Other studies $[9,14,15,17,19]$ selected variables on either data availability and/or clinical expertise, i.e., by including a priori available variables deemed to be relevant to COPD alone. For instance, Chubachi et al. [17] used only comorbidity data, while others used either a combination of lung function and demographic data (i.e., age, BMI, smoking status) $[9,12,14,16,18]$ or a combination of lung function, demographic, comorbidity, and biomarker data $[6,8,10,19]$. Thus far, only a few articles combined all the above information with imaging and/or genetic data $[7,11,13,15]$. The variability in the choice of variables can thus lead to the unpredictability of the characteristics of the derived phenotypes.

Noticeably, seven works used hierarchical analysis $[8,10-13,17,19]$, which is a method in which each cluster is part of a larger cluster and they are all connected to each other like a tree (or dendrogram), whereby the number of clusters is determined by visual inspection [56]. Four studies $[7,9,15,18]$ used k-means clustering, a method that splits the data into mutually exclusive clusters and in which the number of clusters needs to be specified in advance. Finally, two studies $[6,16]$ used a combination of hierarchical and k-means clustering, and one [14] used a combination of hierarchical and discriminant analysis, a technique that discriminates the categories of a dependent variable (e.g., symptoms) and evaluates the accuracy of this classification. 
Table 3

Summary of studies excluded from the systematic analysis.

\begin{tabular}{|c|c|c|c|c|}
\hline $\begin{array}{l}\text { First author and } \\
\text { year of } \\
\text { publication }\end{array}$ & Type and purpose of study & Main findings & COPD phenotypes & Reason for exclusion \\
\hline $\begin{array}{l}\text { Pascoe et al. } \\
\text { (2019) [60] }\end{array}$ & $\begin{array}{l}\text { A randomized parallel group clinical trial } \\
\text { aimed to model the relationships between } \\
\text { eosinophil counts, smoking and treatment } \\
\text { response to inhaled corticosteroids (ICS), } \\
\text { and their interactions, including outcomes } \\
\text { other than exacerbations. }\end{array}$ & $\begin{array}{l}\text { Results showed that assessment of } \\
\text { blood eosinophil count and smoking } \\
\text { status has the potential to optimize ICS } \\
\text { use in clinical practice in patients with } \\
\text { COPD and a history of exacerbations. }\end{array}$ & Not applicable & $\begin{array}{l}\text { Not relevant to } \\
\text { machine learning } \\
\text { methods under study }\end{array}$ \\
\hline $\begin{array}{l}\text { Sivapalan et al. } \\
\text { (2019) [61] }\end{array}$ & $\begin{array}{l}\text { A randomized controlled non-inferiority } \\
\text { trial aimed to determine whether an } \\
\text { algorithm based on blood eosinophil counts } \\
\text { could safely reduce systemic corticosteroid } \\
\text { exposure in patients admitted to hospital } \\
\text { with acute exacerbations of COPD }\end{array}$ & $\begin{array}{l}\text { Results showed that eosinophil-guided } \\
\text { therapy was non-inferior compared } \\
\text { with standard care for the number of } \\
\text { days alive and out of hospital, and } \\
\text { reduced the duration of systemic } \\
\text { corticosteroid exposure, }\end{array}$ & Not applicable & $\begin{array}{l}\text { Not relevant to COPD } \\
\text { phenotyping }\end{array}$ \\
\hline $\begin{array}{l}\text { van Geffen et al. } \\
\text { (2019) [62] }\end{array}$ & $\begin{array}{l}\text { A systematic review and meta-analysis } \\
\text { aimed to evaluate the effects of volume } \\
\text { reduction in the treatment of severe } \\
\text { emphysema }\end{array}$ & $\begin{array}{l}\text { Results showed that lung volume } \\
\text { reduction in patients with severe } \\
\text { emphysema on maximal medical } \\
\text { treatment has clinically meaningful } \\
\text { benefits }\end{array}$ & Not applicable & $\begin{array}{l}\text { Not relevant to COPD } \\
\text { phenotyping }\end{array}$ \\
\hline $\begin{array}{l}\text { Sun et al. (2019) } \\
\text { [63] }\end{array}$ & $\begin{array}{l}\text { A cross-sectional study designed to detect } \\
\text { proteins that were differentially abundant } \\
\text { in COPD frequent exacerbators and assess } \\
\text { whether those expression profiles are } \\
\text { unique among COPD patients }\end{array}$ & $\begin{array}{l}\text { Bioinformatics analyses of proteome } \\
\text { indicated that the immune network for } \\
\text { IgA production and the phenylalanine } \\
\text { metabolism pathway were associated } \\
\text { with frequent exacerbations }\end{array}$ & Not applicable & $\begin{array}{l}\text { Not relevant with the } \\
\text { machine learning } \\
\text { methods under study }\end{array}$ \\
\hline $\begin{array}{l}\text { Pichl et al. (2019) } \\
\text { [64] }\end{array}$ & $\begin{array}{l}\text { A retrospective observational study } \\
\text { investigated the treatment effect of } \\
\text { riociguat and analysed the effect of } \\
\text { riociguat treatment on pulmonary } \\
\text { hypertension }(\mathrm{PH}) \text { in single patients with } \\
\text { PH-COPD }\end{array}$ & $\begin{array}{l}\text { Data showed that riociguat may be } \\
\text { beneficial for treatment of PH-COPD }\end{array}$ & Not applicable & $\begin{array}{l}\text { Not relevant with the } \\
\text { machine learning } \\
\text { methods under study }\end{array}$ \\
\hline $\begin{array}{l}\text { Pragman et al. } \\
\text { (2019) [65] }\end{array}$ & $\begin{array}{l}\text { A case-control observational study aimed to } \\
\text { determine key features that differentiate the } \\
\text { oral and sputum microbiota of frequent } \\
\text { exacerbators (FEs) from the microbiota of } \\
\text { infrequent exacerbators (IEs) during } \\
\text { periods of clinical stability }\end{array}$ & $\begin{array}{l}\text { Data showed that the frequent } \\
\text { exacerbator phenotype is associated } \\
\text { with decreased alpha diversity, beta- } \\
\text { diversity clustering, and changes in } \\
\text { taxonomic abundance }\end{array}$ & Not applicable & $\begin{array}{l}\text { Not relevant with } \\
\text { machine learning } \\
\text { methods under study }\end{array}$ \\
\hline $\begin{array}{l}\text { Xavier et al. } \\
\text { (2019) [33] }\end{array}$ & $\begin{array}{l}\text { An observational cross-sectional study } \\
\text { aiming to investigate COPD phenotypes } \\
\text { according to their levels of physical activity } \\
\text { and sedentary behaviour, as well as body } \\
\text { composition and skeletal muscle strength }\end{array}$ & $\begin{array}{l}\text { Cluster analysis identified three } \\
\text { distinct COPD phenotypes }\end{array}$ & $\begin{array}{l}\text { 1) more physically active, less sedentary } \\
\text { and had better body composition and } \\
\text { lower ADO index, 2) older, less } \\
\text { physically active, more sedentary having } \\
\text { a higher dyspnoea and obstruction (ADO) } \\
\text { index, 3) worse HRQoL, clinical control } \\
\text { and body composition, less physically } \\
\text { active, more sedentary having a higher } \\
\text { ADO index }\end{array}$ & $\begin{array}{l}\text { COPD phenotypes } \\
\text { were not validated } \\
\text { with clinical } \\
\text { meaningful outcomes }\end{array}$ \\
\hline $\begin{array}{l}\text { Incalzi et al. } \\
\text { (2019) [45] }\end{array}$ & $\begin{array}{l}\text { The STORICO Italian observational study } \\
\text { aiming to describe multi-dimensional COPD } \\
\text { phenotypes }\end{array}$ & $\begin{array}{l}\text { Machine learning methods used to } \\
\text { identify five COPD phenotypes }\end{array}$ & $\begin{array}{l}\text { 1) Mild COPD: no night-time symptoms } \\
\text { and the best health status in terms of } \\
\text { quality of life, quality of sleep, level of } \\
\text { depression and anxiety, 2) Mild } \\
\text { emphysematous: prevalent dyspnea in } \\
\text { the early-morning and daytime, 3) Severe } \\
\text { bronchitic: nocturnal and diurnal cough } \\
\text { and phlegm, 4) Severe emphysematous: } \\
\text { nocturnal and diurnal dyspnea, 5) Severe } \\
\text { mixed COPD: higher frequency of } \\
\text { symptoms during } 24 \text { h and worst quality } \\
\text { of life, of sleep and highest levels of } \\
\text { depression and anxiety. }\end{array}$ & $\begin{array}{l}\text { COPD phenotypes } \\
\text { were not validated } \\
\text { with clinical } \\
\text { meaningful outcomes }\end{array}$ \\
\hline $\begin{array}{l}\text { Lainez et al. } \\
\text { (2019) [37] }\end{array}$ & $\begin{array}{l}\text { A retrospective study aiming to identify } \\
\text { asthma and COPD overlap (ACO) } \\
\text { phenotypes }\end{array}$ & $\begin{array}{l}\text { Cluster analysis identified four ACO } \\
\text { phenotypes }\end{array}$ & $\begin{array}{l}\text { 1) overweighed heavy smokers, with an } \\
\text { early onset and a severe disease, 2) } \\
\text { similar patients, with a late onset, 3) and } \\
\text { 4) slighter smokers, presenting a } \\
\text { moderate disease, with early and late } \\
\text { onset respectively }\end{array}$ & $\begin{array}{l}\text { ACO phenotypes were } \\
\text { not validated with } \\
\text { clinical meaningful } \\
\text { outcomes }\end{array}$ \\
\hline $\begin{array}{l}\text { Kukol et al. (2019) } \\
\text { [66] }\end{array}$ & $\begin{array}{l}\text { A cross-sectional study aiming to identify } \\
\text { COPD phenotypes of elderly patients }\end{array}$ & $\begin{array}{l}\text { Cluster analysis identified different } \\
\text { COPD phenotypes for men and women }\end{array}$ & Not applicable & $\begin{array}{l}\text { COPD phenotypes } \\
\text { were not validated } \\
\text { with clinical } \\
\text { meaningful outcomes }\end{array}$ \\
\hline $\begin{array}{l}\text { Pragman et al. } \\
\text { (2019) [67] }\end{array}$ & $\begin{array}{l}\text { A genetic study aiming to determine } \\
\text { features that differentiate the oral, nasal, } \\
\text { and sputum microbiome among subjects } \\
\text { with stable COPD }\end{array}$ & $\begin{array}{l}\text { Data showed associations between } \\
\text { anatomic site and bacterial biomass, } \\
\text { Shannon diversity, and } \beta \text {-diversity. }\end{array}$ & Not applicable & $\begin{array}{l}\text { Not relevant to COPD } \\
\text { phenotyping }\end{array}$ \\
\hline $\begin{array}{l}\text { Haghighi et al. } \\
\text { (2019) [38] }\end{array}$ & $\begin{array}{l}\text { A multi-centre cross-sectional study aiming } \\
\text { to identify COPD phenotypes using }\end{array}$ & & $\begin{array}{l}\text { 1) asymptomatic and showed relatively } \\
\text { normal airway structure and lung }\end{array}$ & $\begin{array}{l}\text { COPD phenotypes } \\
\text { were not validated } \\
\text { (continued on next page) }\end{array}$ \\
\hline
\end{tabular}


Table 3 (continued)

\begin{tabular}{ll}
\hline $\begin{array}{l}\text { First author and } \\
\text { year of } \\
\text { publication }\end{array}$ & Type and purpose of study \\
\hline & $\begin{array}{l}\text { Quantitative computed tomographic (QCT) } \\
\text { imaging }\end{array}$ \\
& \\
& \\
[68] & \\
Bak et al. (2019) & $\begin{array}{l}\text { A retrospective observational study aimed } \\
\text { to assess prognostic impact among } \\
\text { identified clusters in patient with idiopathic } \\
\text { pulmonary fibrosis (IPF) and evaluate the } \\
\text { impact of fibrosis and emphysema on lung } \\
\text { function } \\
\text { A cross-sectional study aimed to identify } \\
\text { novel COPD phenotypes using radiologic } \\
\text { data }\end{array}$ \\
\end{tabular}

(2019) [39] novel COPD phenotypes using radiologic data

Main findings COPD phenotypes

Reason for exclusion

Cluster analysis identified patient groups with distinct skeletal muscle molecular responses to rehabilitation

Data showed that after 2 years of follow-up, most of the COPD patients maintained their cluster assignment

Data showed that the new GOLD 2017 ABCD classification does not predict all-cause and respiratory mortality more accurately than the previous GOLD systems from 2007 to 2011 Response to treatments such as exercise training and spironolactone varies among complex HF phenotypes

Results showed that machine learning methods improved the prediction accuracy of COPD progression Data showed that the estimated overall prevalence of COPD in China in 2014-15 was $13.6 \%$

Data showed that small airways disease is a pathological feature in mild and moderate COPD

Results showed that this novel method can be used in analyzing a wholegenome genotyping data

\section{Cluster analysis identified five} phenotypes of comorbidities

(2018) [46]

Cluster analysis did not reveal a clinical-metabolomic stratification
A pilot study aiming to characterize patients with COPD, based on the metabolomic profiling of peripheral blood and exhaled breath condensate (EBC) within the context of defined clinical and demographic variables.
Imaging-based cluster analysis identified four possible COPD phenotypes
Cluster analysis identified distinct phenotypes, which predicted prognosis of clinical outcome

Cluster analysis identified four COPD phenotypes function except airway wall thickening and moderate emphysema, 2) obese females showed an increase of tissue fraction at inspiration, minimal emphysema, and the lowest progression rate of emphysema, 3 ) older males showed small airway narrowing and a decreased tissue fraction at expiration, both indicating air-trapping, 4) lean males were likely to be severe COPD subjects showing the highest progression rate of emphysema Not applicable

with clinical meaningful outcomes Not relevant to COPD phenotyping

1) mild emphysema with severe airway changes, severe airflow limitation, and high exacerbation risk, 2) mild emphysema with moderate airway changes, mild airflow limitation, and mild dyspnea, 3) severe emphysema with moderate airway changes, severe airflow limitation, and increased dyspnea, 4) moderate emphysema with mild airway changes, mild airflow limitation, low exacerbation risk, and mild dyspnea Not applicable

1) younger age, mild airway limitation, few symptoms, 2) intermediate (clinical characteristics between clusters 1 and 3), 3) older age, severe airway limitation and highly symptomatic

Not applicable

Not applicable

Not applicable

Not applicable

Not applicable

COPD phenotypes were not validated with clinical meaningful outcomes

COPD phenotypes were not validated with clinical meaningful outcomes COPD phenotypes were not validated with clinical meaningful outcomes

Not relevant to COPD phenotyping and to machine learning methods under study

Not relevant to COPD phenotyping

Not relevant to COPD phenotyping

Not relevant to COPD phenotyping

Not relevant to COPD phenotyping

Not applicable

Not relevant with the machine learning methods under study

1) included cardiac profile, 2) included less comorbidities, 3) included metabolic syndrome, apnea and anxiety-depression, 4) included denutrition and osteoporosis, 5) included bronchiectasis

Not applicable

COPD phenotypes were not validated with clinical meaningful outcomes superior to the strata set by the GOLD consensus.
COPD phenotypes were not validated with clinical meaningful outcomes 
Table 3 (continued)

\begin{tabular}{|c|c|c|c|c|}
\hline $\begin{array}{l}\text { First author and } \\
\text { year of } \\
\text { publication }\end{array}$ & Type and purpose of study & Main findings & COPD phenotypes & Reason for exclusion \\
\hline $\begin{array}{l}\text { de Vries et al. } \\
\text { (2018) [47] }\end{array}$ & $\begin{array}{l}\text { A multi-centre cross-sectional study to } \\
\text { capture clinical/inflammatory phenotypes } \\
\text { in patients with chronic airway disease } \\
\text { using an electronic nose (eNose) in a } \\
\text { training and validation set }\end{array}$ & $\begin{array}{l}\text { Cluster analysis identified five } \\
\text { combined asthma and COPD } \\
\text { phenotypes }\end{array}$ & $\begin{array}{l}\text { 1) Asthma and COPD: predominantly } \\
\text { females, high BMI, high symptom scores, } \\
\text { low FeNO, no inflammation measured in } \\
\text { blood, } 2 \text { ) Asthma and COPD: } \\
\text { predominantly males, high circulating } \\
\text { eosinophil counts, high FeNO, low use of } \\
\text { oral corticosteroids, } 3 \text { ) Asthma and } \\
\text { COPD: predominately non-Caucasian, } \\
\text { poor lung function, eosinophil blood } \\
\text { counts of } 0.45 \pm 1.3 \times 109 \text { cells } \mathrm{L}-1 \text {, } \\
\text { lowest exacerbation rate in the past } 3 \\
\text { months, no OCS use, low use of ICS, } 4 \text { ) } \\
\text { Asthma and COPD: predominantly } \\
\text { atopic, high circulating neutrophil blood } \\
\text { counts, highest number of exacerbations } \\
\text { per person in the past } 3 \text { months, 5) fewer } \\
\text { COPD patients, best postbronchodilator } \\
\text { FEV1, relatively low exacerbation rate } \\
\text { per person in the past } 3 \text { months }\end{array}$ & $\begin{array}{l}\text { COPD phenotypes } \\
\text { were not validated } \\
\text { with clinical } \\
\text { meaningful outcomes }\end{array}$ \\
\hline $\begin{array}{l}\text { Le Rouzic et al. } \\
\text { (2018) [77] }\end{array}$ & $\begin{array}{l}\text { A prospective observational study aimed to } \\
\text { confirm the existence of the frequent } \\
\text { exacerbator phenotype }\end{array}$ & $\begin{array}{l}\text { Data confirmed the existence of the } \\
\text { frequent exacerbator and the threshold } \\
\text { to define this phenotype }\end{array}$ & Not applicable & $\begin{array}{l}\text { COPD phenotypes } \\
\text { were not validated } \\
\text { with clinical } \\
\text { meaningful outcomes }\end{array}$ \\
\hline $\begin{array}{l}\text { Vazquez } \\
\text { Guillamet et al. } \\
\text { (2018) [32] }\end{array}$ & $\begin{array}{l}\text { A retrospective observational study aimed } \\
\text { to identify COPD phenotypes from } \\
\text { electronic medical records }\end{array}$ & $\begin{array}{l}\text { Cluster analysis identified nine COPD } \\
\text { phenotypes }\end{array}$ & $\begin{array}{l}\text { 1) depression-chronic obstructive } \\
\text { pulmonary disease, 2) coronary artery } \\
\text { disease-chronic obstructive pulmonary } \\
\text { disease, 3) cerebrovascular } \\
\text { disease-chronic obstructive pulmonary } \\
\text { disease, 4) malignancy-chronic } \\
\text { obstructive pulmonary disease, 5) } \\
\text { advanced malignancy-chronic } \\
\text { obstructive pulmonary disease, 6) } \\
\text { diabetes mellitus-chronic kidney } \\
\text { disease-chronic obstructive pulmonary } \\
\text { disease, 7) young age-few } \\
\text { comorbidities-high readmission } \\
\text { rates-chronic obstructive pulmonary } \\
\text { disease, 8) atopy-chronic obstructive } \\
\text { pulmonary disease, 9) advanced } \\
\text { disease-chronic obstructive pulmonary } \\
\text { disease }\end{array}$ & $\begin{array}{l}\text { COPD phenotypes } \\
\text { were not validated } \\
\text { with clinical } \\
\text { meaningful outcomes }\end{array}$ \\
\hline $\begin{array}{l}\text { Hall et al. (2018) } \\
\text { [78] }\end{array}$ & $\begin{array}{l}\text { An observational prospective study aimed } \\
\text { to determine the extent to which } \\
\text { multimorbidity is associated with long-term } \\
\text { survival following acute myocardial } \\
\text { infarction (AMI) }\end{array}$ & $\begin{array}{l}\text { Three multimorbidity phenotype } \\
\text { clusters that were significantly } \\
\text { associated with loss in life expectancy } \\
\text { were identified and should be a } \\
\text { concomitant treatment target to } \\
\text { improve cardiovascular outcomes. }\end{array}$ & Not applicable & $\begin{array}{l}\text { Not relevant to COPD } \\
\text { phenotyping }\end{array}$ \\
\hline $\begin{array}{l}\text { Das et al. (2018) } \\
\text { [79] }\end{array}$ & $\begin{array}{l}\text { A review of machine learning methods in } \\
\text { the diagnosis of COPD }\end{array}$ & $\begin{array}{l}\text { The application of artificial intelligence } \\
\text { has produced promising results in the } \\
\text { diagnosis of COPD }\end{array}$ & Not applicable & $\begin{array}{l}\text { Not relevant to COPD } \\
\text { phenotyping }\end{array}$ \\
\hline $\begin{array}{l}\text { Merchant et al. } \\
\text { (2018) [80] }\end{array}$ & $\begin{array}{l}\text { A prospective observational study aimed to } \\
\text { assess the impact of digital intervention on } \\
\text { asthma health resource utilization }\end{array}$ & $\begin{array}{l}\text { Results showed that digital health } \\
\text { interventions can be incorporated into } \\
\text { routine clinical practice, and their use } \\
\text { may contribute to improved outcomes } \\
\text { including reduced healthcare } \\
\text { utilization }\end{array}$ & Not applicable & $\begin{array}{l}\text { Not relevant to COPD } \\
\text { phenotyping }\end{array}$ \\
\hline $\begin{array}{l}\text { Radin et al. (2017) } \\
\text { [31] }\end{array}$ & $\begin{array}{l}\text { A cross-sectional study aimed to identify } \\
\text { novel COPD phenotypes based on computed } \\
\text { tomography (CT) densitometry }\end{array}$ & $\begin{array}{l}\text { Cluster analysis showed the CT } \\
\text { densitometry identified two distinct } \\
\text { phenotypes of COPD }\end{array}$ & $\begin{array}{l}\text { Cluster } 1 \text { has subjects with decreased } \\
\text { FEV1, FEV/FVC, FEF at } 25-75 \% \text { of FVC } \\
\text { and BMI and increased residual volume } \\
\text { and total lung capacity compared to } \\
\text { cluster } 2\end{array}$ & $\begin{array}{l}\text { The derived } \\
\text { phenotypes were not } \\
\text { validated with clinical } \\
\text { meaningful outcomes }\end{array}$ \\
\hline $\begin{array}{l}\text { Christenson et al. } \\
\text { (2017) [81] }\end{array}$ & $\begin{array}{l}\text { A randomized placebo-controlled clinical } \\
\text { trial aimed to explore airway epithelial } \\
\text { mucin gene expression heterogeneity in } \\
\text { COPD }\end{array}$ & $\begin{array}{l}\text { Cluster analysis identified that } 2 \text { COPD } \\
\text { subgroups in which either MUC5AC or } \\
\text { MUC5B gene expression is elevated. } \\
\text { These subgroups are associated with } \\
\text { specific inflammatory patterns }\end{array}$ & $\begin{array}{l}2 \text { COPD subgroups in which either } \\
\text { MUC5AC or MUC5B gene expression is } \\
\text { elevated }\end{array}$ & $\begin{array}{l}\text { The derived } \\
\text { phenotypes were not } \\
\text { validated with clinical } \\
\text { meaningful outcomes }\end{array}$ \\
\hline $\begin{array}{l}\text { Kästle et al. } \\
\text { (2017) [82] }\end{array}$ & $\begin{array}{l}\text { A genetic study aimed to identify specific } \\
\text { miRNAs implicated in controlling Th17 } \\
\text { differentiation }\end{array}$ & $\begin{array}{l}\text { Results showed evidence of miRNAs } \\
\text { involvement in controlling the } \\
\text { differentiation and function of T helper } \\
\text { cells, offering useful tools to study and } \\
\text { modify Th17-mediated inflammation. }\end{array}$ & Not applicable & $\begin{array}{l}\text { Not relevant with the } \\
\text { machine learning } \\
\text { methods under study }\end{array}$ \\
\hline $\begin{array}{l}\text { Fouda et al. } \\
\text { (2017) [83] }\end{array}$ & $\begin{array}{l}\text { A prospective observational study on the } \\
\text { association between osteoporosis and }\end{array}$ & $\begin{array}{l}\text { Results showed that emphysematous } \\
\text { phenotype is not a risk factor for }\end{array}$ & Not applicable & $\begin{array}{l}\text { Not relevant with the } \\
\text { machine learning } \\
\text { methods under study } \\
\text { (continued on next page) }\end{array}$ \\
\hline
\end{tabular}


Table 3 (continued)

First author and

First author and Type and purpose of study

year of

publication

emphysema in a model that includes these

(2017) [84]

A review on bronchiectasis characterization

Fingleton et al. (2017) [48]

A cross-sectional observational study aiming to compare the phenotypes of airways disease in two separate populations (China and New Zealand)

Zarei et al. (2017) A randomized placebo-controlled trial [35] aimed to identify COPD phenotypes using proteomic data

Hirai et al. (2017) A prospective observational study aimed to [85] clarify the discriminant factors for assigning the asthma-COPD overlap phenotype

Lee et al. (2017) A national survey aimed to identify [49] subtypes in patients with mild-to-moderate airflow limitation and to appreciate their clinical and socioeconomic implications osteoporosis independently of BMI, FEV1, and PaO2.

Key developments in the bronchiectasis Not applicable

field include the establishment of international disease registries and characterization of disease phenotypes using cluster analysis and biological data.

Cluster analysis identified five COPD phenotypes that were similar in both populations

Cluster analysis identified three COPD phenotypes

Data showed that the asthma-COPD overlap phenotype was characterized by peripheral blood eosinophilia and higher levels of IgE despite the Th2-low endotype.

Cluster analysis identified five phenotypes with different level of health care utilization endotype
Haldar et al. (2017) [86]

Çolak et al. (2017) [87]

\section{Maddocks et al. (2016) [88]}

Lange et al. (2016) [89]

Papi et al. (2016)

[24]

Ning et al. (2016)

[40]
A genetic study aimed to assess whether the balance between the two dominant bacterial groups (Gammaproteobacteria (G) and Firmicutes (F)) in COPD sputum samples might reveal a subgroup with a bacterial community structure change at exacerbation that was restored to baseline on recovery and potentially reflects effective antibiotic treatment.

A prospective observational study aimed to investigate the prognosis of individuals with asymptomatic and symptomatic, undiagnosed COPD in the general population in Denmark.

A randomized placebo-controlled trial aimed to assess the effectiveness of neuromuscular electrical stimulation (NMES) as a home-based exercise therapy A prospective observational study aimed to investigate the long-term prognosis of individuals with different types of chronic airway disease and asthma-COPD overlap

A prospective observational study aimed to define COPD phenotypes and identify biomarkers and/or genetic parameters that help to predict disease progression

A cross-sectional analysis aimed to identify distinct COPD phenotypes
Results showed that the G:F ratio at exacerbation can be determined on a timescale compatible with decisions regarding clinical management

Individuals with undiagnosed, symptomatic COPD had an increased risk of exacerbations, pneumonia, and death. Individuals with undiagnosed, asymptomatic COPD had an increased risk of exacerbations and pneumonia. Data showed that NMES improves functional exercise capacity in patients with severe COPD by enhancing quadriceps muscle mass and function. Data showed that the prognosis of individuals with asthma-COPD overlap is poor and seems to be affected by the age of recognition of asthma, being worst in those with late asthma onset (after 40 years of age)

The study highlights some of the progress in phenotyping the heterogeneity of the disease that have been made thanks to the analyses of this longitudinal study

Cluster analysis identified four phenotypes
1) severe late-onset asthma/COPD overlap group, 2) moderately severe early-onset asthma/COPD overlap group, 3) moderate to severe asthma group with type 2 predominant disease, 4 and 5) minimal airflow obstruction, differentiated by age of onset. The third cluster had less emphysema and worse disease-related quality of life, despite similar levels of lung function impairment than the other two groups peripheral blood eosinophilia and higher levels of IgE despite the Th2-low

1) near-normal: oldest mean age, highest FEV1, 2) asthmatic: youngest, lowest prescription rate, despite the highest proportion of self-reported wheezing, 3) chronic obstructive pulmonary disease (COPD): male predominant and al current or ex-smokers, high prescription rate of respiratory medicine, 4) asthmatic-overlap: high prescription rate of respiratory medicine, 5) COPDoverlap: male predominant and all current or ex-smokers, high prescription rate of respiratory medicine.

Not applicable

Not applicable

Not applicable

Not applicable

Not applicable

1) COPD patients with moderate to severe airflow limitation, 2) asthma and COPD patients with heavy smoking, airflow limitation and increased airways reversibility, 3) patients having less smoking and normal pulmonary function with wheezing but no chronic cough, 4)
Not relevant to COPD phenotyping and machine learning methods under study

COPD phenotypes were not validated with clinical meaningful outcomes

COPD phenotypes were not validated with clinical meaningful outcomes COPD phenotypes were not validated with clinical meaningful outcomes

COPD phenotypes were not validated with clinical meaningful outcomes

Not relevant to COPD phenotyping

Not relevant to machine learning methods under study

Not relevant to COPD phenotyping

Not relevant to COPD phenotyping

Not relevant to machine learning methods under study

COPD phenotypes were not validated with clinical meaningful outcomes 
Table 3 (continued)

\begin{tabular}{|c|c|c|c|c|}
\hline $\begin{array}{l}\text { First author and } \\
\text { year of } \\
\text { publication }\end{array}$ & Type and purpose of study & Main findings & COPD phenotypes & Reason for exclusion \\
\hline
\end{tabular}

publication

Rootmensen et al. A cross-sectional study aimed to identify (2016) [41] COPD phenotypes in an outpatient population

Sekiya et al. (2016) [50]

A prospective observational study aimed to examine the clinical characteristics and heterogeneity of patients with severe or lifethreatening asthma exacerbation.
Sato et al. (2016) A retrospective study aiming to identify [90]

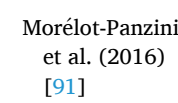

Roche et al. (2016) [92]

Martínez-García et al. (2016) [93]

Batista-Navarro et al. (2016)

[94]

Labuzzetta et al. (2016) [95]

Kaluarachchi et al. (2016) [96]

Obeidat et al. (2015) [97]

Kim et al. (2015) [98]

Hübenthal et al. (2015) [99]

Lee et al. (2014) [100]

A cross-sectional study investigating the sleep apnea patients

An observational cohort study aimed to bronchiectasis

A cross-sectional qualitative study that compared a manual performing task of mining algorithm

A genetic cross-sectional study that uses phenotypes

A case-control study aimed to determine with tobacco smoking investigate molecular mechanisms underlying variations in lung function

A cross-sectional study aimed to identify omics data

A case-control study that used genetic accurately predict inflammatory diseases An observational genetic study aimed to investigate the clinical and genetic
Cluster analysis identified five distinct asthma phenotypes
Cluster analysis identified four COPD phenotypes chronic bronchitis patients with normal pulmonary function and chronic cough asthma hospitalizations in the past year,

Cluster analysis identified three phenotypes; idiopathic pulmonary fibrosis (IPF) with PE is a distinct phenotype with poor prognosis The MDP can identify an affective/ emotional dimension of dyspnea and contribute to phenotypic description of patients

The study identified genetic variants mapping to hypoxia response elements genetic variability of COPD and obstructive identify phenotypes for non-cystic fibrosis COPD phenotype curation to that of a textmachine learning methods to predict COPD perturbed biochemical functions associated

A genome-wide association study aimed to novel lung disease phenotypes using multiprofiling and machine learning methods to heterogeneity in subjects with mild airflow
Using cluster analysis, it was possible to identify distinct phenotypes

Text-mining algorithms were more efficient in facilitating the curation of COPD phenotypes

Machine learning methods showed that isoform expression data have high accuracy in predicting phenotypes Results showed that combining multiplatform metabolic phenotyping with knowledge-based mapping gives mechanistic insights into disease development

The system genetics approach identified lung tissue genes driving the variation in lung function and susceptibility to COPD

Cluster analysis identified subclusters with distinct clinical and biomolecular characteristics

The proposed miRNA signature is of relevance for the etiology of inflammatory bowel disease (IBD) Results showed that GOLD 1 subjects show substantial clinical heterogeneity, which is at least 1) patients with a history of extensive cigarette smoking, airway obstruction without signs of emphysema, 2) patients with features of the emphysematous type of COPD, 3) patients with characteristics of allergic asthma, 4) patients with features suggesting an overlap syndrome of atopic asthma and COPD

1) younger-onset asthma with severe symptoms at baseline, including limitation of activities, a higher frequency of treatment with oral corticosteroids and short-acting betaagonists, and a higher frequency of 2) predominantly composed of elderly females, with the highest frequency of comorbid, chronic hyperplastic rhinosinusitis/nasal polyposis, and a long disease duration, 3) allergic asthma without inhaled corticosteroid use at baseline. Patients in this cluster had a higher frequency of atopy, including allergic rhinitis and furred pet hypersensitivity, and a better prognosis during hospitalization compared with the other clusters, 4) elderly males with concomitant chronic obstructive pulmonary disease (COPD), 5) very mild symptoms at baseline according to the patient questionnaires, $41 \%$ had previously been hospitalized for asthma Not applicable

COPD phenotypes were not validated with clinical meaningful outcomes

Not relevant to COPD phenotyping; not validated with clinical meaningful outcomes

Not relevant to COPD phenotyping

Not applicable

COPD phenotypes were not validated with clinical meaningful outcomes Not relevant to COPD phenotyping

Not relevant to COPD phenotyping

Not relevant to methods under study; not validated with clinical outcomes Predicted phenotypes not validated with clinical outcomes Not relevant to COPD phenotyping

Not applicable

Not relevant to COPD phenotyping

Not applicable

Not relevant to COPD phenotyping; not validated with clinical meaningful outcomes Not relevant to COPD phenotyping

The derived phenotypes were not 
Table 3 (continued)

\begin{tabular}{|c|c|c|c|c|}
\hline $\begin{array}{l}\text { First author and } \\
\text { year of } \\
\text { publication }\end{array}$ & Type and purpose of study & Main findings & COPD phenotypes & Reason for exclusion \\
\hline & $\begin{array}{l}\text { limitation in spirometry grade } 1 \text { defined by } \\
\text { the Global Initiative for COPD }\end{array}$ & $\begin{array}{l}\text { partially related to genetic } \\
\text { heterogeneity. }\end{array}$ & & $\begin{array}{l}\text { validated with clinical } \\
\text { meaningful outcomes }\end{array}$ \\
\hline $\begin{array}{l}\text { Uzun et al. (2014) } \\
\text { [101] }\end{array}$ & $\begin{array}{l}\text { A randomized placebo-controlled trial } \\
\text { aimed to investigate whether patients with } \\
\text { COPD who had received treatment for three } \\
\text { or more exacerbations in the previous year } \\
\text { would have a decrease in exacerbation rate } \\
\text { when maintenance treatment with } \\
\text { azithromycin was added to standard care }\end{array}$ & $\begin{array}{l}\text { Data showed that maintenance } \\
\text { treatment with azithromycin } \\
\text { significantly decreased the } \\
\text { exacerbation rate compared with } \\
\text { placebo }\end{array}$ & Not applicable & $\begin{array}{l}\text { Not relevant to COPD } \\
\text { phenotyping }\end{array}$ \\
\hline $\begin{array}{l}\text { Brightling et al. } \\
\text { (2014) [102] }\end{array}$ & $\begin{array}{l}\text { A randomized placebo-controlled trial } \\
\text { aimed to establish whether benralizumab } \\
\text { reduces acute exacerbations of COPD in } \\
\text { patients with eosinophilia and COPD }\end{array}$ & $\begin{array}{l}\text { Results showed that compared with } \\
\text { placebo, benralizumab did not reduce } \\
\text { the rate of acute exacerbations of COPD }\end{array}$ & Not applicable & $\begin{array}{l}\text { Not relevant to COPD } \\
\text { phenotyping }\end{array}$ \\
\hline $\begin{array}{l}\text { Kon et al. (2014) } \\
\text { [103] }\end{array}$ & $\begin{array}{l}\text { Three prospective observational studies } \\
\text { aimed to assess the he minimum clinically } \\
\text { important difference (MCID) for the COPD } \\
\text { Assessment Test (CAT) in patients with } \\
\text { COPD }\end{array}$ & $\begin{array}{l}\text { The most reliable estimate of the } \\
\text { minimum important difference of the } \\
\text { CAT is } 2 \text { points }\end{array}$ & Not applicable & $\begin{array}{l}\text { Not relevant to COPD } \\
\text { phenotyping }\end{array}$ \\
\hline $\begin{array}{l}\text { Köhnlein et al. } \\
\text { (2014) [104] }\end{array}$ & $\begin{array}{l}\text { A prospective randomized controlled } \\
\text { clinical trial aimed to investigate the effect } \\
\text { of long-term non-invasive positive pressure } \\
\text { ventilation (NPPV), targeted to markedly } \\
\text { reduce hypercapnia, on survival in patients } \\
\text { with advanced, stable hypercapnic COPD }\end{array}$ & $\begin{array}{l}\text { Results showed that the addition of } \\
\text { long-term NPPV to standard treatment } \\
\text { improves survival of patients with } \\
\text { hypercapnic, stable COPD when NPPV } \\
\text { is targeted to greatly reduce } \\
\text { hypercapnia. }\end{array}$ & Not applicable & $\begin{array}{l}\text { Not relevant to COPD } \\
\text { phenotyping }\end{array}$ \\
\hline $\begin{array}{l}\text { Jones et al. (2014) } \\
\text { [105] }\end{array}$ & $\begin{array}{l}\text { A retrospective study aimed to investigate } \\
\text { patterns of health-care use and } \\
\text { comorbidities present in patients in the } \\
\text { period before diagnosis of chronic } \\
\text { obstructive pulmonary disease (COPD) }\end{array}$ & $\begin{array}{l}\text { Data showed that opportunities to } \\
\text { diagnose COPD at an earlier stage are } \\
\text { being missed, and could be improved } \\
\text { by case-finding in patients with lower } \\
\text { respiratory tract symptoms and } \\
\text { concordant long-term comorbidities. }\end{array}$ & Not applicable & $\begin{array}{l}\text { Not relevant to COPD } \\
\text { phenotyping }\end{array}$ \\
\hline $\begin{array}{l}\text { Zheng et al. } \\
\text { (2014) [106] }\end{array}$ & $\begin{array}{l}\text { A randomized placebo-controlled trial } \\
\text { aimed to assess whether } \mathrm{N} \text {-acetylcysteine } \\
\text { could reduce the rate of exacerbations in } \\
\text { patients with COPD }\end{array}$ & $\begin{array}{l}\text { Data showed that in Chinese patients } \\
\text { with moderate-to-severe COPD, long- } \\
\text { term use of N-acetylcysteine } 600 \mathrm{mg} \\
\text { twice daily can prevent exacerbations, } \\
\text { especially in disease of moderate } \\
\text { severity. }\end{array}$ & Not applicable & $\begin{array}{l}\text { Not relevant to COPD } \\
\text { phenotyping }\end{array}$ \\
\hline $\begin{array}{l}\text { Corhay et al. } \\
\text { (2014) [107] }\end{array}$ & $\begin{array}{l}\text { A cross-sectional study aimed to summarize } \\
\text { the current data available about the } \\
\text { phenotypes of this disease }\end{array}$ & $\begin{array}{l}\text { Cluster analysis can help to identify } \\
\text { more precise definition of COPD } \\
\text { phenotypes }\end{array}$ & Not applicable & $\begin{array}{l}\text { COPD phenotypes } \\
\text { were not validated } \\
\text { with clinical } \\
\text { meaningful outcomes }\end{array}$ \\
\hline $\begin{array}{l}\text { Moore et al. } \\
\quad(2014)[108]\end{array}$ & $\begin{array}{l}\text { A cross-sectional study aiming to } \\
\text { understand the interactions between } \\
\text { inflammation and clinical asthma } \\
\text { subphenotypes }\end{array}$ & $\begin{array}{l}\text { Cluster analysis identified four } \\
\text { phenotypes associated with asthma } \\
\text { severity }\end{array}$ & Not applicable & $\begin{array}{l}\text { Not relevant to COPD } \\
\text { phenotyping }\end{array}$ \\
\hline $\begin{array}{l}\text { Qiao et al. (2014) } \\
\text { [109] }\end{array}$ & $\begin{array}{l}\text { A simulation study investigating the } \\
\text { association between genetic loci and } \\
\text { complex phenotypes }\end{array}$ & $\begin{array}{l}\text { Cluster analysis can be useful in } \\
\text { genome sequencing studies for pairing } \\
\text { genomic regions with complex } \\
\text { phenotypes }\end{array}$ & Not applicable & $\begin{array}{l}\text { Not relevant to COPD } \\
\text { phenotyping }\end{array}$ \\
\hline $\begin{array}{l}\text { DiSantostefano } \\
\text { et al. (2014) } \\
\text { [110] }\end{array}$ & $\begin{array}{l}\text { Baseline data of two clinical trials were used } \\
\text { to identify risk groups for pneumonia }\end{array}$ & $\begin{array}{l}\text { Cluster analysis can identified distinct } \\
\text { patient groups at risk of pneumonia }\end{array}$ & Not applicable & $\begin{array}{l}\text { Not relevant to COPD } \\
\text { phenotyping }\end{array}$ \\
\hline $\begin{array}{l}\text { Vogelmeier et al. } \\
\text { (2013) [111] }\end{array}$ & $\begin{array}{l}\text { A randomized parallel group trial aimed to } \\
\text { compare the efficacy, safety, and } \\
\text { tolerability of QVA149 versus salmeterol- } \\
\text { fluticasone (SFC) over } 26 \text { weeks in patients } \\
\text { with moderate-to-severe COPD }\end{array}$ & $\begin{array}{l}\text { Results suggested the potential of dual } \\
\text { bronchodilation as a treatment option } \\
\text { for non-exacerbating symptomatic } \\
\text { COPD patients }\end{array}$ & Not applicable & $\begin{array}{l}\text { Not relevant to COPD } \\
\text { phenotyping }\end{array}$ \\
\hline $\begin{array}{l}\text { Franciosi et al. } \\
\text { (2013) [112] }\end{array}$ & $\begin{array}{l}\text { Four clinical trials aimed to assess the } \\
\text { efficacy and safety of a novel inhaled dual } \\
\text { phosphodiesterase } 3 \text { (PDE3) and PDE } 4 \\
\text { inhibitor, RPL554 for its ability to act as a } \\
\text { bronchodilator and anti-inflammatory drug }\end{array}$ & $\begin{array}{l}\text { Data showed that inhaled RPL554 is an } \\
\text { effective and well tolerated } \\
\text { bronchodilator, bronchoprotector, and } \\
\text { anti-inflammatory drug }\end{array}$ & Not applicable & $\begin{array}{l}\text { Not relevant to COPD } \\
\text { phenotyping }\end{array}$ \\
\hline $\begin{array}{r}\text { Decramer et al. } \\
\text { (2013) [113] }\end{array}$ & $\begin{array}{l}\text { A randomized parallel group study aimed to } \\
\text { compare the efficacy and safety of } \\
\text { indacaterol and tiotropium in patients with } \\
\text { COPD }\end{array}$ & $\begin{array}{l}\text { Data showed that Indacaterol and } \\
\text { tiotropium provided clinically relevant } \\
\text { improvements in lung function with } \\
\text { comparable safety profiles. }\end{array}$ & Not applicable & $\begin{array}{l}\text { Not relevant to COPD } \\
\text { phenotyping }\end{array}$ \\
\hline $\begin{array}{l}\text { Dransfield et al. } \\
\text { (2013) [114] }\end{array}$ & $\begin{array}{l}\text { Two parallel group randomized controlled } \\
\text { trials aimed to investigate whether } \\
\text { fluticasone furoate and vilanterol would } \\
\text { prevent more exacerbations than would } \\
\text { vilanterol alone }\end{array}$ & $\begin{array}{l}\text { Results showed that addition of } \\
\text { fluticasone furoate to vilanterol was } \\
\text { associated with a decreased rate of } \\
\text { moderate and severe exacerbations of } \\
\text { COPD in patients with a history of } \\
\text { exacerbation, but was also associated } \\
\text { with an increased pneumonia risk }\end{array}$ & Not applicable & $\begin{array}{l}\text { Not relevant to COPD } \\
\text { phenotyping }\end{array}$ \\
\hline $\begin{array}{l}\text { Wedzicha et al. } \\
\text { (2013) [115] }\end{array}$ & $\begin{array}{l}\text { A randomized parallel-group study aimed to } \\
\text { evaluate the effect of dual, long acting }\end{array}$ & $\begin{array}{l}\text { Results suggested potential of dual } \\
\text { bronchodilation as a treatment option }\end{array}$ & Not applicable & $\begin{array}{l}\text { Not relevant to COPD } \\
\text { phenotyping }\end{array}$ \\
\hline
\end{tabular}


Table 3 (continued)

\begin{tabular}{|c|c|c|c|c|}
\hline $\begin{array}{l}\text { First author and } \\
\text { year of } \\
\text { publication }\end{array}$ & Type and purpose of study & Main findings & COPD phenotypes & Reason for exclusion \\
\hline & $\begin{array}{l}\text { inhaled bronchodilator treatment on } \\
\text { exacerbations in patients with severe and } \\
\text { very severe chronic obstructive pulmonary } \\
\text { disease (COPD) }\end{array}$ & $\begin{array}{l}\text { for patients with severe and very severe } \\
\text { COPD. }\end{array}$ & & \\
\hline $\begin{array}{l}\text { Rabe et al. (2013) } \\
\text { [116] }\end{array}$ & $\begin{array}{l}\text { A randomized parallel-group study aimed to } \\
\text { establish whether ADRB2 polymorphisms } \\
\text { differentially affected COPD exacerbation } \\
\text { outcomes in response to tiotropium versus } \\
\text { salmeterol. }\end{array}$ & $\begin{array}{l}\text { Data showed limited evidence for the } \\
\text { use of ADRB2 polymorphisms for } \\
\text { predicting LABA treatment response }\end{array}$ & Not applicable & $\begin{array}{l}\text { Not relevant to COPD } \\
\text { phenotyping }\end{array}$ \\
\hline $\begin{array}{r}\text { Siedlinski et al. } \\
\text { (2013) [117] }\end{array}$ & $\begin{array}{l}\text { A case-control study aimed to estimate } \\
\text { direct and indirect effects of genetic loci on } \\
\text { COPD development using mediation } \\
\text { analysis }\end{array}$ & $\begin{array}{l}\text { This study confirms the existence of } \\
\text { direct effects of the AGPHD1/CHRNA3, } \\
\text { IREB2, FAM13A and HHIP loci on } \\
\text { COPD development. }\end{array}$ & Not applicable & $\begin{array}{l}\text { Not relevant to COPD } \\
\text { phenotyping and } \\
\text { machine learning } \\
\text { methods under study }\end{array}$ \\
\hline $\begin{array}{l}\text { Gouzi et al. (2013) } \\
\text { [118] }\end{array}$ & $\begin{array}{l}\text { A cross-sectional study aimed to test } \\
\text { whether muscle fiber atrophy and increased } \\
\text { oxidative stress constitute the attributes of } \\
\text { validated COPD phenotypes }\end{array}$ & $\begin{array}{l}\text { Data showed that demonstrates that the } \\
\text { muscle heterogeneity is the translation } \\
\text { of different phenotypes of the disease. }\end{array}$ & Not applicable & $\begin{array}{l}\text { COPD phenotypes } \\
\text { were not validated } \\
\text { with clinical } \\
\text { meaningful outcomes }\end{array}$ \\
\hline $\begin{array}{l}\text { Fens et al. (2013) } \\
\text { [42] }\end{array}$ & $\begin{array}{l}\text { A cross-sectional study aimed to identify } \\
\text { subphenotypes of COPD in a community- } \\
\text { based population of heavy (ex-) smokers }\end{array}$ & $\begin{array}{l}\text { Cluster analysis identified four COPD } \\
\text { phenotypes }\end{array}$ & $\begin{array}{l}\text { 1) mild COPD, limited symptoms and } \\
\text { good quality of life, 2) low lung function, } \\
\text { combined emphysema and chronic } \\
\text { bronchitis and a distinct breath } \\
\text { molecular profile, 3) emphysema } \\
\text { predominant COPD with preserved lung } \\
\text { function, 4) highly symptomatic COPD } \\
\text { with mildly impaired lung function. }\end{array}$ & $\begin{array}{l}\text { COPD phenotypes } \\
\text { were not validated } \\
\text { with clinical } \\
\text { meaningful outcomes }\end{array}$ \\
\hline $\begin{array}{l}\text { Shaykhiev et al. } \\
\text { (2013) [119] }\end{array}$ & $\begin{array}{l}\text { A genetic study investigating the } \\
\text { association between CXCL14 gene, cancer } \\
\text { and COPD }\end{array}$ & $\begin{array}{l}\text { Data showed that smoking-induced } \\
\text { gene expression is a potential link } \\
\text { between smoking-associated airway } \\
\text { epithelial injury, COPD, and lung } \\
\text { cancer. }\end{array}$ & Not applicable & $\begin{array}{l}\text { Not relevant to COPD } \\
\text { phenotyping }\end{array}$ \\
\hline $\begin{array}{l}\text { Carolan et al. } \\
\text { (2013) [120] }\end{array}$ & $\begin{array}{l}\text { A review that discusses advances in } \\
\text { describing phenotypic variability in asthma } \\
\text { and COPD }\end{array}$ & $\begin{array}{l}\text { The authors suggest that better } \\
\text { understanding of the heterogeneity of } \\
\text { the disease through phenotyping will } \\
\text { improve care and reduce potential } \\
\text { adverse effects from unnecessary } \\
\text { therapies }\end{array}$ & Not applicable & $\begin{array}{l}\text { Not relevant to } \\
\text { methods under study. } \\
\text { i.e. a review - not } \\
\text { original research study }\end{array}$ \\
\hline $\begin{array}{l}\text { Basagaña et al. } \\
\text { (2013) [39] }\end{array}$ & $\begin{array}{l}\text { In this article the authors developed a } \\
\text { framework of applying imputation to } \\
\text { missing values of a cluster analysis }\end{array}$ & $\begin{array}{l}\text { The proposed framework deals with } \\
\text { uncertainty in definiens the number of } \\
\text { clusters, the variable selection and } \\
\text { allocation of patients to clusters }\end{array}$ & Not applicable & $\begin{array}{l}\text { Not relevant to the } \\
\text { studies under review }\end{array}$ \\
\hline $\begin{array}{l}\text { Toraldo et al. } \\
\text { (2012) [121] }\end{array}$ & $\begin{array}{l}\text { A review article that discusses and refines } \\
\text { the concept of desaturator phenotypes in } \\
\text { COPD with pulmonary hypertension }(\mathrm{PH})\end{array}$ & $\begin{array}{l}\text { Cluster analysis can identify a pattern } \\
\text { of phenotypic markers that could be } \\
\text { used as a framework for future } \\
\text { diagnosis and research }\end{array}$ & Not applicable & $\begin{array}{l}\text { Not relevant to COPD } \\
\text { phenotyping and } \\
\text { machine learning } \\
\text { methods under study }\end{array}$ \\
\hline $\begin{array}{l}\text { Travers et al. } \\
\text { (2012) [122] }\end{array}$ & $\begin{array}{l}\text { In a letter to the editors the authors discuss } \\
\text { the possibility of re-examining the } \\
\text { classification of airways disease to identify } \\
\text { disease subgroups that may respond to } \\
\text { treatments in different ways. }\end{array}$ & $\begin{array}{l}\text { The authors conclude that } \\
\text { classification analysis can be used to } \\
\text { derive allocation rules that allow } \\
\text { disease groups identified through } \\
\text { cluster analysis to be prospectively } \\
\text { identified in the real world. This will } \\
\text { enable trials to test interventions in } \\
\text { putative phenotypes, a necessary step } \\
\text { towards personalised medicine for } \\
\text { airways disease. }\end{array}$ & Not applicable & $\begin{array}{l}\text { Not relevant to } \\
\text { machine learning } \\
\text { methods under study }\end{array}$ \\
\hline $\begin{array}{l}\text { Toraldo et al. } \\
\text { (2011) [123] }\end{array}$ & $\begin{array}{l}\text { A cross-sectional study aimed to discuss and } \\
\text { refine the concept of phenotyping } \\
\text { desaturators in COPD and shows a possible } \\
\text { pattern which could be used as a framework } \\
\text { for future research. }\end{array}$ & $\begin{array}{l}\text { The study suggests that COPD } \\
\text { phenotyping can facilitate our } \\
\text { understanding and management of } \\
\text { COPD }\end{array}$ & Not applicable & $\begin{array}{l}\text { Not relevant to } \\
\text { machine learning } \\
\text { methods under study }\end{array}$ \\
\hline $\begin{array}{l}\text { Bafadhel et al. } \\
\text { (2011) [36] }\end{array}$ & $\begin{array}{l}\text { A cross-sectional study aimed to study the } \\
\text { application of CT imaging in the } \\
\text { multidimensional approach to phenotyping } \\
\text { patients with COPD }\end{array}$ & $\begin{array}{l}\text { Cluster analysis identified three } \\
\text { clusters, two of which were } \\
\text { emphysema predominant and the third } \\
\text { characterized by a heterogeneous } \\
\text { combination of emphysema and } \\
\text { bronchiectasis }\end{array}$ & $\begin{array}{l}\text { 1) emphysema (EM) predominant, 2) } \\
\text { bronchiectasis (BE) predominant, 3) } \\
\text { heterogeneous combination of EM and } \\
\mathrm{BE}\end{array}$ & $\begin{array}{l}\text { The derived } \\
\text { phenotypes were not } \\
\text { validated with clinical } \\
\text { meaningful outcomes }\end{array}$ \\
\hline $\begin{array}{l}\text { Bafadhel et al. } \\
\text { (2011) [43] }\end{array}$ & $\begin{array}{l}\text { A prospective observational study aimed to } \\
\text { investigate biomarker expression in COPD } \\
\text { exacerbations to identify biologic clusters } \\
\text { and determine biomarkers that recognize } \\
\text { clinical COPD exacerbation phenotypes }\end{array}$ & $\begin{array}{l}\text { Cluster analysis identified four distinct } \\
\text { biologic exacerbation clusters }\end{array}$ & $\begin{array}{l}\text { 1) bacterial-predominant, 2) viral- } \\
\text { predominant, 3) eosinophilic- } \\
\text { predominant, 4) limited changes in the } \\
\text { inflammatory profile }\end{array}$ & $\begin{array}{l}\text { COPD phenotypes } \\
\text { were not validated } \\
\text { with clinical } \\
\text { meaningful outcomes }\end{array}$ \\
\hline $\begin{array}{l}\text { Fingleton et al. } \\
\text { (2011) [124] }\end{array}$ & $\begin{array}{l}\text { In a letter to the editors the authors discuss } \\
\text { the tailoring of treatment regiments to } \\
\text { patients with different COPD phenotypes }\end{array}$ & $\begin{array}{l}\text { The author acknowledge the challenge } \\
\text { to determine distinct phenotypes and } \\
\text { suggest that if these phenotypes are } \\
\text { validated with response to treatment }\end{array}$ & Not applicable & $\begin{array}{l}\text { Not relevant to } \\
\text { methods under study, } \\
\text { i.e. a review - not } \\
\text { original research study }\end{array}$ \\
\hline
\end{tabular}


Table 3 (continued)

\begin{tabular}{|c|c|c|c|c|}
\hline $\begin{array}{l}\text { First author and } \\
\text { year of } \\
\text { publication }\end{array}$ & Type and purpose of study & Main findings & COPD phenotypes & Reason for exclusion \\
\hline $\begin{array}{l}\text { Shirtcliffe et al. } \\
\text { (2011) [125] }\end{array}$ & $\begin{array}{l}\text { This review aimed to a better understanding } \\
\text { of the distinct disorders of airways disease } \\
\text { with the potential to inform on underlying } \\
\text { mechanisms, risk factors, natural history, } \\
\text { monitoring and treatment. }\end{array}$ & $\begin{array}{l}\text { then can be potentially used to target } \\
\text { treatments specifically to patients } \\
\text { The authors conclude that by further } \\
\text { defining the distinct phenotypes that } \\
\text { make up the syndromes of asthma and } \\
\text { COPD could lead to treatments } \\
\text { specifically targeted for defined } \\
\text { phenotypic groups. }\end{array}$ & Not applicable & $\begin{array}{l}\text { Not relevant to } \\
\text { methods under study, } \\
\text { i.e. a review - not } \\
\text { original research study }\end{array}$ \\
\hline $\begin{array}{l}\text { Sharma et al. } \\
\text { (2010) [126] }\end{array}$ & $\begin{array}{l}\text { A study used data from two clinical trials } \\
\text { aimed to identify subject clusters in one } \\
\text { study and replicate the findings in the } \\
\text { second study }\end{array}$ & $\begin{array}{l}\text { Cluster analysis identified three } \\
\text { subjects clusters in one study that were } \\
\text { replicated in the second study }\end{array}$ & Not applicable & $\begin{array}{l}\text { The derived } \\
\text { phenotypes were not } \\
\text { validated with clinical } \\
\text { meaningful outcomes }\end{array}$ \\
\hline $\begin{array}{l}\text { Jo et al. (2010) } \\
\text { [127] }\end{array}$ & $\begin{array}{l}\text { A cross-sectional observational study aimed } \\
\text { to classify the phenotypes in elderly } \\
\text { subjects with obstructive lung disease } \\
\text { (OLD) }\end{array}$ & $\begin{array}{l}\text { Cluster analysis identified three } \\
\text { phenotypes in elderly patients with } \\
\text { OLD }\end{array}$ & Not applicable & $\begin{array}{l}\text { The derived } \\
\text { phenotypes were not } \\
\text { validated with clinical } \\
\text { meaningful outcomes }\end{array}$ \\
\hline $\begin{array}{l}\text { Cho et al. (2010) } \\
\text { [44] }\end{array}$ & $\begin{array}{l}\text { An observational genetic study aimed to } \\
\text { identify subtypes of severe emphysema }\end{array}$ & $\begin{array}{l}\text { Cluster analysis identified four } \\
\text { phenotypes in a group of sever } \\
\text { emphysema patients }\end{array}$ & $\begin{array}{l}\text { 1) emphysema predominant, 2) } \\
\text { bronchodilator responsive, with higher } \\
\text { FEV1, 3) discordant, with a lower FEV1 } \\
\text { despite less severe emphysema and lower } \\
\text { airway wall thickness, 4) airway } \\
\text { predominant. }\end{array}$ & $\begin{array}{l}\text { The derived } \\
\text { phenotypes were not } \\
\text { validated with clinical } \\
\text { meaningful outcomes }\end{array}$ \\
\hline $\begin{array}{l}\text { Sobradillo et al. } \\
\text { (2010) [128] }\end{array}$ & $\begin{array}{l}\text { In this article the authors review the } \\
\text { knowledge in the topic of COPD phenotypes }\end{array}$ & & Not applicable & $\begin{array}{l}\text { Not relevant to the } \\
\text { purpose of the review } \\
\text { under study }\end{array}$ \\
\hline $\begin{array}{l}\text { Weatherall et al. } \\
\text { (2010) [129] }\end{array}$ & $\begin{array}{l}\text { In this article the authors discuss the } \\
\text { advantages and disadvantages of cluster } \\
\text { analysis to characterize different types of } \\
\text { airways disorders }\end{array}$ & $\begin{array}{l}\text { The author conclude that cluster } \\
\text { analysis can help to better } \\
\text { understanding the true patterns of } \\
\text { airway disorders and could lead to } \\
\text { different pharmacological treatments } \\
\text { and other interventions directed at } \\
\text { specific phenotypic group }\end{array}$ & Not applicable & $\begin{array}{l}\text { Not relevant to } \\
\text { machine learning } \\
\text { methods under study }\end{array}$ \\
\hline $\begin{array}{l}\text { Paoletti et al. } \\
\text { (2009) [130] }\end{array}$ & $\begin{array}{l}\text { A cross-sectional study aimed to assess the } \\
\text { presence of hidden structures in data } \\
\text { corresponding to the different COPD } \\
\text { phenotypes observed in clinical practice }\end{array}$ & $\begin{array}{l}\text { Data showed that using cluster analysis } \\
\text { can identify phenotypes for } \\
\text { understanding the results of } \\
\text { pharmacologic trials; clinician's } \\
\text { approach to patient treatment and } \\
\text { COPD natural history. }\end{array}$ & Not applicable & $\begin{array}{l}\text { The derived } \\
\text { phenotypes were not } \\
\text { validated with clinical } \\
\text { meaningful outcomes }\end{array}$ \\
\hline $\begin{array}{l}\text { Weatherall et al. } \\
\text { (2009) [51] }\end{array}$ & $\begin{array}{l}\text { A cross-sectional study aimed to explore } \\
\text { clinical phenotypes in a community } \\
\text { population with airways disease }\end{array}$ & $\begin{array}{l}\text { Cluster analysis identified five distinct } \\
\text { phenotypes of airflow obstruction }\end{array}$ & $\begin{array}{l}\text { 1) severe and markedly variable airflow } \\
\text { obstruction with features of atopic } \\
\text { asthma, chronic bronchitis and } \\
\text { emphysema, 2) features of emphysema } \\
\text { alone, 3) atopic asthma with eosinophilic } \\
\text { airways inflammation, 4) mild airflow } \\
\text { obstruction without other dominant } \\
\text { phenotypic features, 5) chronic } \\
\text { bronchitis in nonsmokers }\end{array}$ & $\begin{array}{l}\text { The derived } \\
\text { phenotypes were not } \\
\text { validated with clinical } \\
\text { meaningful outcomes }\end{array}$ \\
\hline $\begin{array}{l}\text { Pistolesi et al. } \\
\text { (2008) [131] }\end{array}$ & $\begin{array}{l}\text { A cross-sectional study aimed to ascertain } \\
\text { whether COPD phenotypes reflecting } \\
\text { different mechanisms of airflow limitation } \\
\text { could be clinically identified }\end{array}$ & $\begin{array}{l}\text { Results showed that patients with } \\
\text { COPD can be assigned a clinical } \\
\text { phenotype reflecting the prevalent } \\
\text { mechanism of airflow limitation }\end{array}$ & Not applicable & $\begin{array}{l}\text { Not relevant to COPD } \\
\text { phenotyping and } \\
\text { machine learning } \\
\text { methods under study }\end{array}$ \\
\hline $\begin{array}{l}\text { Patel et al. (2008) } \\
\text { [132] }\end{array}$ & $\begin{array}{l}\text { An observational study aiming to assess the } \\
\text { association between airway wall thickening } \\
\text { and emphysema at the severity of COPD }\end{array}$ & $\begin{array}{l}\text { Airway wall thickening and } \\
\text { emphysema make independent } \\
\text { contributions to airflow obstruction in } \\
\text { COPD. }\end{array}$ & Not applicable & $\begin{array}{l}\text { Not relevant with } \\
\text { machine learning } \\
\text { methods under study }\end{array}$ \\
\hline $\begin{array}{l}\text { Kodavanti et al. } \\
\text { (2006) }[133]\end{array}$ & $\begin{array}{l}\text { An animal study investigating whether } \\
\text { spontaneously hypertensive (SH) rats may } \\
\text { offer a better model of experimental } \\
\text { bronchitis and subsequent COPD } \\
\text { phenotypes }\end{array}$ & $\begin{array}{l}\text { Data showed that sulfur dioxide (SO2) } \\
\text { exposure } \mathrm{SH} \text { rats may yield a relevant } \\
\text { experimental model of bronchitis }\end{array}$ & Not applicable & $\begin{array}{l}\text { Not relevant to COPD } \\
\text { phenotyping }\end{array}$ \\
\hline $\begin{array}{l}\text { Wardlaw et al. } \\
\text { (2005) [134] }\end{array}$ & $\begin{array}{l}\text { An article that discusses the use of a new } \\
\text { taxonomy for mutli-dimensional } \\
\text { phenotyping }\end{array}$ & $\begin{array}{l}\text { The authors suggest that development } \\
\text { of this taxonomy will require a much } \\
\text { more complete and sophisticated } \\
\text { correlation of the many variables that } \\
\text { uses complex statistical tools such as } \\
\text { cluster analysis }\end{array}$ & Not applicable & $\begin{array}{l}\text { Not relevant machine } \\
\text { learning methods } \\
\text { under study }\end{array}$ \\
\hline $\begin{array}{l}\text { Hackett et al. } \\
\text { (2003) [135] }\end{array}$ & $\begin{array}{l}\text { A genetic study investigating the } \\
\text { association between antioxidant-related } \\
\text { genes and smoking-induced chronic } \\
\text { bronchitis }\end{array}$ & $\begin{array}{l}\text { Data showed that antioxidant-related } \\
\text { genes may be useful genetic markers in } \\
\text { assessing susceptibility to smoking- } \\
\text { induced chronic bronchitis }\end{array}$ & Not applicable & $\begin{array}{l}\text { Not relevant to COPD } \\
\text { phenotyping }\end{array}$ \\
\hline
\end{tabular}


Table 4

List of all potential COPD phenotypes by group of clinical relevance.

\begin{tabular}{|c|c|c|}
\hline \multirow{3}{*}{$\begin{array}{l}\text { Phenotypes } \\
\text { Mild COPD } \\
\text { Moderate COPD }\end{array}$} & \multicolumn{2}{|l|}{ Groups } \\
\hline & Physician defined & Lung function-based severity including poor lung \\
\hline & severity & function and symptoms \\
\hline \multicolumn{3}{|l|}{ Severe COPD } \\
\hline Atopy & \multicolumn{2}{|l|}{ Asthma phenotype } \\
\hline Mild asthma & \multicolumn{2}{|l|}{ Severity of asthma } \\
\hline \multicolumn{3}{|l|}{ Moderate to severe asthma } \\
\hline Cardiovascular disease & \multicolumn{2}{|l|}{ Comorbidities } \\
\hline \multicolumn{3}{|l|}{ Diabetes } \\
\hline \multicolumn{3}{|l|}{ Anxiety } \\
\hline \multicolumn{3}{|l|}{ Depression } \\
\hline \multicolumn{3}{|l|}{ Gastroesophageal reflux disease (GERD) } \\
\hline Worse lung function but fewer symptoms & \multicolumn{2}{|c|}{ Lung function-based severity } \\
\hline $\begin{array}{l}\text { Worse lung function with more symptoms, more exacerbations, faster FEV1 decline and greatest } \\
\text { SGRQ decline }\end{array}$ & $\begin{array}{l}\text { Lung function-based } \\
\text { severity }\end{array}$ & Health-related quality of life including breathlessness \\
\hline $\begin{array}{l}\text { Patients with additional symptoms and moderate airflow obstruction and more exacerbations } \\
\text { requiring hospitalization }\end{array}$ & Lung function-based & rity \\
\hline Bacterial-predominant & Clinical severity & \\
\hline \multicolumn{3}{|l|}{ Viral-predominant } \\
\hline \multicolumn{3}{|l|}{ Eosinophilic-predominant } \\
\hline No/mild obstruction and minimal emphysema & \multicolumn{2}{|c|}{ Underlying disease processes for COPD } \\
\hline \multicolumn{3}{|l|}{ Emphysema predominant (EM) } \\
\hline \multicolumn{3}{|l|}{ Bronchiectasis predominant (BE) } \\
\hline \multicolumn{3}{|l|}{ Heterogeneous combination of EM and BE } \\
\hline \multicolumn{3}{|l|}{ Mild emphysematous: prevalent dyspnea in the early-morning and daytime } \\
\hline \multicolumn{3}{|l|}{ Severe emphysema } \\
\hline \multicolumn{3}{|l|}{ Severe emphysematous: nocturnal and diurnal dyspnea } \\
\hline \multicolumn{3}{|l|}{ Chronic bronchitis patients with normal pulmonary function and chronic cough } \\
\hline \multicolumn{3}{|l|}{ Severe bronchitis: nocturnal and diurnal cough and phlegm } \\
\hline Asthma and COPD overlap & Distinct phenotype & \\
\hline $\begin{array}{l}\text { Mild to moderate airflow limitation, absent or mild emphysema and dyspnea, normal nutritional } \\
\text { status, limited comorbidities }\end{array}$ & Distinct phenotype & \\
\hline Obesity & Distinct phenotype & \\
\hline Younger patients with fewer symptoms and exacerbations and mild airflow obstruction & Distinct phenotype & \\
\hline Young patients with mild airflow obstruction, few symptoms and infrequent severe exacerbations & Distinct phenotype & \\
\hline Young patients with moderate to severe airflow limitation, few comorbidities & Distinct phenotype & \\
\hline Older patients with severe airway limitation and highly symptomatic & Distinct phenotype & \\
\hline $\begin{array}{l}\text { Older patients with high rates of cardiovascular comorbidities and diabetes, but less severe } \\
\text { respiratory disease }\end{array}$ & Distinct phenotype & \\
\hline Older patients with high prevalence of comorbidities and obesity & Distinct phenotype & \\
\hline $\begin{array}{l}\text { Older patients with mild airflow obstruction, few symptoms, infrequent severe exacerbations but } \\
\text { higher mortality }\end{array}$ & Distinct phenotype & \\
\hline $\begin{array}{l}\text { Older patients with moderate respiratory disease, dyspnea, history of severe exacerbations and } \\
\text { underweight }\end{array}$ & Distinct phenotype & \\
\hline Very severe respiratory disease with low rates of cardiovascular comorbidities and diabetes & Distinct phenotype & \\
\hline Mild respiratory disease and low rates of comorbidities & Distinct phenotype & \\
\hline Overweighed heavy smokers, with an early or late onset and a severe disease & Distinct phenotype & \\
\hline $\begin{array}{l}\text { Patients having less smoking and normal pulmonary function with wheezing but no chronic } \\
\text { cough }\end{array}$ & Distinct phenotype & \\
\hline $\begin{array}{l}\text { Patients with a history of extensive cigarette smoking, airway obstruction without signs of } \\
\text { emphysema }\end{array}$ & Distinct phenotype & \\
\hline $\begin{array}{l}\text { Asymptomatic with relatively normal airway structure and lung function except airway wall } \\
\text { thickening and moderate emphysema }\end{array}$ & Distinct phenotype & \\
\hline $\begin{array}{l}\text { Obese females with an increase of tissue fraction at inspiration, minimal emphysema, and the } \\
\text { lowest progression rate of emphysema }\end{array}$ & Distinct phenotype & \\
\hline $\begin{array}{l}\text { Older males with small airway narrowing and a decreased tissue fraction at expiration, both } \\
\text { indicating air-trapping }\end{array}$ & Distinct phenotype & \\
\hline $\begin{array}{l}\text { Lean males were likely to be severe COPD subjects showing the highest progression rate of } \\
\text { emphysema }\end{array}$ & Distinct phenotype & \\
\hline
\end{tabular}

\subsection{Missing values}

We note that regardless of the method used, an important aspect of these cluster analysis approaches is the handling of missing values. Indeed, most of the reviewed studies failed to address this issue. Research tended to use non-missing data to form COPD clusters without considering which phenotypes might have been formed if patients with missing data had been included in the analysis or if only a portion of them had been excluded. Only two studies $[6,15]$ considered alternative methods for assessing the impact of excluding patients on the formation of COPD phenotypes. Pikoula et al. [6] performed a sensitivity analysis by excluding all patients with a diagnostic code for asthma and identified four clusters. Notably, the atopic cluster did not present a strong enough discriminant ability to form a separate cluster. Thus, atopic patients were categorized as belonging to either the anxiety/depression or the not-comorbid phenotype. Garcia-Aymerich [15] instead considered the use of multiple imputation when implementing the cluster analysis [57], allowing simulated values to replace the missing ones and thereby enabling the use of data from all patients. 
Table 5

Data characteristics and methods for the identification of COPD phenotypes in the reviewed studies.

\begin{tabular}{|c|c|c|}
\hline Study & Data used in the clustering analysis & Data reduction and clustering methods \\
\hline Yoon et al. (2019) [9] & $\begin{array}{l}\text { Age, BMI, smoking status, history of asthma, COPD assessment test (CAT) score, pre-bronchodilator } \\
\text { FEV1\% predicted, diffusing capacity of carbon monoxide } \% \text { predicted }\end{array}$ & K-means \\
\hline $\begin{array}{l}\text { Pikoula et al. (2019) } \\
\text { [6] }\end{array}$ & BMI, smoking status, atopy, GINA ${ }^{a}$ classification, eosinophilia, comorbidities & $\begin{array}{l}\text { Multiple correspondence analysis (MCA), k- } \\
\text { means, and hierarchical clustering }\end{array}$ \\
\hline Kim et al. (2018) [10] & BMI, Charlson comorbidity index, SGRQ ${ }^{\mathrm{b}}$ total score, FEV1 & Factor analysis and hierarchical clustering \\
\hline Kim et al. (2017) [11] & Clinical, physiological and imaging data & PCA and hierarchical cluster analysis \\
\hline Burgel et al. (2017) [8] & $\begin{array}{l}\text { Age, BMI, FEV1\% predicted, } \text { mMRC }^{\mathrm{C}} \text { dyspnea scale, exacerbation in the past } 12 \text { months, } \\
\text { comorbidities }\end{array}$ & $\begin{array}{l}\text { Factor analysis for mixed data (FAMD) and } \\
\text { hierarchical clustering }\end{array}$ \\
\hline Peters et al. (2017) [14] & FEV1\% predicted, BMI, exercise capacity, subjective symptoms, fatigue, quality of life & Hierarchical and discriminant cluster analysis \\
\hline $\begin{array}{l}\text { Chubachi et al. (2016) } \\
\text { [17] }\end{array}$ & Comorbidity data (e.g., cardiovascular diseases and diabetes) & Hierarchical cluster analysis \\
\hline $\begin{array}{l}\text { Fingleton et al. (2015) } \\
\text { [19] }\end{array}$ & $\begin{array}{l}\text { Respiratory history and comorbidities, lung function, reversibility testing, biomarkers, disease } \\
\text { control and health status }\end{array}$ & Hierarchical cluster analysis \\
\hline Chen et al. (2014) [16] & $\begin{array}{l}\text { Age, lung function (FEV1\% predicted), BMI, history of severe exacerbations, mMRC, SpO 2, Charlson } \\
\text { Index }\end{array}$ & PCA, hierarchical, and k-means clustering \\
\hline $\begin{array}{l}\text { Castaldi et al. (2014) } \\
\text { [7] }\end{array}$ & $\begin{array}{l}\text { Demographic and clinical characteristics, spirometry, genome-wide SNP genotyping data, } \\
\text { inspiratory and expiratory CT scans }\end{array}$ & Factor analysis and k-means clustering \\
\hline $\begin{array}{l}\text { Altenburg et al. (2012) } \\
\text { [18] }\end{array}$ & Age, BMI, quadriceps force, body plethysmography, exercise testing & K-means cluster analysis \\
\hline $\begin{array}{l}\text { Burgel et al. (2010) } \\
\text { [12] }\end{array}$ & Age, symptoms, spirometry, BMI, exacerbations, health and psychological status & PCA and hierarchical cluster analysis \\
\hline $\begin{array}{l}\text { Burgel et al. (2012) } \\
\text { [13] }\end{array}$ & Age, symptoms, health status, body plethysmography, DLCO ${ }^{\mathrm{d}}$, CT scan, comorbidities & PCA and hierarchical cluster analysis \\
\hline $\begin{array}{l}\text { Garcia-Aymerich et al. } \\
\text { (2011) [15] }\end{array}$ & $\begin{array}{l}\text { Symptoms, health status, body composition, plethysmography, CT scan, saliva and serum, exercise } \\
\text { testing }\end{array}$ & K-means cluster analysis \\
\hline
\end{tabular}

${ }^{a}$ GINA: Global Initiative for Asthma.

b SGRQ: St George's Respiratory Questionnaire.

c mMRC: Modified Medical Research Council.

d DL $\mathrm{CO}_{\mathrm{C}}$ : Diffusing capacity of the lungs for carbon monoxide.

\section{Discussion}

There are several implications of clinical and medical relevance in using machine learning methods to extract data from different sources, such as radiology, imaging or genetics, to identify clinically relevant COPD phenotypes. In sum, these include a better understanding of the natural history of the disease, the opportunity to more accurately identify high risk patient profiles, the prospect of early diagnosis and target treatments specific to certain phenotypes - along with the limitation of potentially adverse effects of unnecessary treatments, and the ability to make better and more precise predictions of treatment outcomes, thereby improving the prognosis of the disease and optimizing the use of health care resources.

Building on the evidence emerging from this review, we can identify several recommendations for future research using cluster analysis to identify COPD phenotypes; these are summarized in Table 6. These strategies include the use of large samples to make clinically meaningful associations and the handling of missing data to assess the robustness of the results.

Moving forward, in keeping with Bourbeau et al. [58], we suggest that regardless of the clustering method chosen, COPD-derived phenotypes should be validated both internally and externally. This aspect is central because clustering methods are data-driven techniques, thus the derived clusters might be subject to spurious groupings.
As such, best practices in deriving COPD phenotypes include the utilization of prospective longitudinal data, which allows the assessment of variability and stability of features over time, as well as the use of cohorts from different settings to obtain the full spectrum of COPD phenotypes. The former recommendation implies carrying out large observational longitudinal cohort studies with at least a 3-year followup, as currently seen in the CALIBER [6] and ECLIPSE [24] studies. The latter proposal suggests using cohorts from different populations and settings to fully capture the heterogeneity of COPD. In this respect, we also envision the benefit of analysing cohorts including genetic information, such as COPDGene [7] or the UK Biobank database [59]. The immediate advantages of using such databases will be the opportunity to analytically and jointly assess patients' clinical characteristics (eg, lung functionality), comorbidities, and biomarker data to strengthen the robustness of the COPD phenotypes as well as to better understand the underlying biological mechanisms of the condition.

Ensuring clarity in the choice of variables used for identifying COPD phenotypes is another crucial recommendation for research using cluster analysis. This selection should always be evidence-based through experts' opinions and/or published works to avoid choosing variables that might not be clinically relevant [58]. At the same time, we recognize that this approach may lead to previously unidentified patient characteristics being overlooked. Thus, we suggest that a reasonable compromise moving forward would be to use available evidence

Table 6

Best practices recommended for the identification of clinically validated COPD phenotypes using clustering analysis.

\begin{tabular}{|c|c|c|c|c|}
\hline Prospective longitudinal data & External validation & Large samples & $\begin{array}{l}\text { Handling of missing } \\
\text { data }\end{array}$ & Choice of variables and cluster analysis \\
\hline $\begin{array}{l}\text { Use longitudinal prospective data } \\
\text { over a long period of time from a } \\
\text { large database (e.g., CALIBER, } \\
\text { UK Biobank) }\end{array}$ & $\begin{array}{l}\text { Cross-validation with different databases from } \\
\text { multiple settings (in different parts of the world), } \\
\text { and validation against clinically meaningful } \\
\text { endpoints (e.g., exacerbations, response to therapy, } \\
\text { mortality) }\end{array}$ & $\begin{array}{l}\text { Use large samples, } \\
\text { ideally with more } \\
\text { than } 1000 \text { patients }\end{array}$ & $\begin{array}{l}\text { Multiple imputation } \\
\text { methods and } \\
\text { sensitivity analysis }\end{array}$ & $\begin{array}{l}\text { Through a combination of expert } \\
\text { opinions, evidence-based data and } \\
\text { literature reviews, data reduction } \\
\text { methods, and cluster analysis }\end{array}$ \\
\hline
\end{tabular}


alongside clustering analysis. As such, the combination of hierarchical, k-means clustering, and clinical judgment appears to be the most suitable approach to specify the correct number of clusters leading to the identification of novel COPD phenotypes.

\section{Conclusions}

This article reviewed research published in the last decade on COPD phenotypes identified using cluster analysis and validated with clinically meaningful outcomes. To the best of our knowledge, this is one of the first works addressing such a systematization of the COPD literature. Moreover, it puts forward key recommendations to improve the study design, variables selection, external validation, and handling of missing data of prospective studies.

Finally, we believe that future research should be tasked with further investigating COPD phenotype(s) whose characteristics have not yet been fully explored. For instance, the "fast decliner" phenotype [10,26, 27], characterized by young patients with COPD with a fast decline in their lung function, as well as the cardiovascular comorbidity [6,13,25] characterized by differences in age, sex and high rates of hospital admission for AECOPD represent promising issues which are still largely unaddressed. Whichever the phenotype, we are hopeful that the insights presented here will soon enable research to better characterize additional patient determinants of COPD phenotypes and explore their association with responses to therapy while possibly developing more targeted treatments.

\section{Funding}

This research did not receive any specific grant from funding agencies in the public, commercial, or ot-for-profit sectors.

\section{References}

[1] NHS inform on Chronic obstructive pulmonary disease. https://www.nhsinform. scot/illnesses-and-conditions/lungs-and-airways/copd/ch ronic-obstructive-pulmonary-disease\#about-copd. (Accessed 15 February 2020).

[2] World Health Organization on chronic respiratory diseases and COPD. https://www.who.int/respiratory/copd/en/. (Accessed 15 February 2020).

[3] Global Initiative for Chronic Obstructive Lung Disease, Pocket guide to COPD diagnosis, management and prevention, Report, https://goldcopd.org/wp-c ontent/uploads/2018/11/GOLD-2019-POCKET-GUIDE-FINAL_WMS.pdf, 2019. (Accessed 15 February 2020).

[4] P.R. Burgel, J.L. Paillasseur, N. Roche, Identification of clinical phenotypes using cluster analyses in COPD patients with multiple comorbidities, BioMed Res. Int. 2014 (2014), 420134.

[5] D.M. Halpin, H.J. de Jong, V. Carter, D. Skinner, D. Price, Distribution, temporal stability and appropriateness of therapy of patients with COPD in the UK in relation to GOLD 2019, EClinicalMedicine 14 (2019 Sep 1) 32-41.

[6] M. Pikoula, J.K. Quint, F. Nissen, H. Hemingway, L. Smeeth, S. Denaxas, Identifying clinically important COPD sub-types using data-driven approaches in primary care population based electronic health records, BMC Med. Inf. Decis. Making 19 (1) (2019 Dec) 86.

[7] P.J. Castaldi, J. Dy, J. Ross, et al., Cluster analysis in the COPDGene study identifies subtypes of smokers with distinct patterns of airway disease and emphysema, Thorax 69 (5) (2014 May 1) 416-423.

[8] P.R. Burgel, J.L. Paillasseur, W. Janssens, et al., A simple algorithm for the identification of clinical COPD phenotypes, Eur. Respir. J. 50 (5) (2017 Nov 1) 1701034.

[9] H.Y. Yoon, S.Y. Park, C.H. Lee, et al., Prediction of first acute exacerbation using COPD subtypes identified by cluster analysis, Int. J. Chronic Obstr. Pulm. Dis. 14 (2019) 1389.

[10] W.J. Kim, V. Gupta, M. Nishimura, et al., Identification of chronic obstructive pulmonary disease subgroups in 13 Asian cities, Int. J. Tubercul. Lung Dis. 22 (7) (2018 Jul 1) 820-826.

[11] S. Kim, M.N. Lim, Y. Hong, S.S. Han, S.J. Lee, W.J. Kim, A cluster analysis of chronic obstructive pulmonary disease in dusty areas cohort identified three subgroups, BMC Pulm. Med. 17 (1) (2017 Dec) 209.

[12] P.R. Burgel, J.L. Paillasseur, D. Caillaud, et al., Clinical COPD phenotypes: a novel approach using principal component and cluster analyses, Eur. Respir. J. 36 (3) (2010 Sep 1) 531-539.

[13] P.R. Burgel, J.L. Paillasseur, B. Peene, et al., Two distinct chronic obstructive pulmonary disease (COPD) phenotypes are associated with high risk of mortality, PloS One 7 (12) (2012).

[14] J.B. Peters, L.M. Boer, J. Molema, Y.F. Heijdra, J.B. Prins, J.H. Vercoulen, Integral health status-based cluster analysis in moderate-severe copd patients identifies three clinical phenotypes: relevant for treatment as usual and pulmonary rehabilitation, Int. J. Behav. Med. 24 (4) (2017 Aug 1) 571-583.

[15] J. Garcia-Aymerich, F.P. Gómez, M. Benet, et al., Identification and prospective validation of clinically relevant chronic obstructive pulmonary disease (COPD) subtypes, Thorax 66 (5) (2011 May 1) 430-437.

[16] C.Z. Chen, L.Y. Wang, C.Y. Ou, C.H. Lee, C.C. Lin, T.R. Hsiue, Using cluster analysis to identify phenotypes and validation of mortality in men with COPD, Lung 192 (6) (2014 Dec 1) 889-896.

[17] S. Chubachi, M. Sato, N. Kameyama, et al., Identification of five clusters of comorbidities in a longitudinal Japanese chronic obstructive pulmonary disease cohort, Respir. Med. 117 (2016 Aug 1) 272-279.

[18] W.A. Altenburg, M.H. de Greef, N.H. Ten Hacken, J.B. Wempe, A better response in exercise capacity after pulmonary rehabilitation in more severe COPD patients, Respir. Med. 106 (5) (2012 May 1) 694-700.

[19] J. Fingleton, J. Travers, M. Williams, et al., Treatment responsiveness of phenotypes of symptomatic airways obstruction in adults, J. Allergy Clin. Immunol. 136 (3) (2015 Sep 1) 601-609.

[20] Everitt B. (1974). Cluster Analysis Heinemann. London.

[21] H.K. Reddel, M.G. de Verdier, A. Agustí, et al., Prospective observational study in patients with obstructive lung disease: NOVELTY design, ERJ open research 5 (1) (2019 Feb 1), 00036-2018.

[22] Study of COPD Subgroups and Biomarkers (SPIROMICS). [ClinicalTrials.Gov Identifier: NCT01969344].

[23] Chart Review of Patients with COPD, Using Electronic Medical Records and Artificial Intelligence (BigCOPData) [ClinicalTrials.Gov Identifier: NCT04206098].

[24] A. Papi, M.S. Magnoni, C.C. Muzzio, G. Benso, A. Rizzi, Phenomenology of COPD: interpreting phenotypes with the ECLIPSE study, Monaldi Arch. Chest Dis. 83 (1-2) (2016 Oct 14).

[25] A. Agusti, P.M. Calverley, B. Celli, et al., Characterisation of COPD heterogeneity in the ECLIPSE cohort, Respir. Res. 11 (1) (2010 Dec 1) 122.

[26] J.R. Hurst, J. Vestbo, A. Anzueto, et al., Susceptibility to exacerbation in chronic obstructive pulmonary disease, N. Engl. J. Med. 363 (12) (2010 Sep 16) $1128-1138$.

[27] J. Vestbo, L.D. Edwards, P.D. Scanlon, et al., Changes in forced expiratory volume in 1 second over time in COPD, N. Engl. J. Med. 365 (13) (2011 Sep 29) 1184-1192.

[28] M. Nishimura, H. Makita, K. Nagai, et al., Annual change in pulmonary function and clinical phenotype in chronic obstructive pulmonary disease, Am. J. Respir. Crit. Care Med. 185 (1) (2012 Jan 1) 44-52.

[29] J.F. Donohue, N. Herje, G. Crater, K. Rickard, Characterization of airway inflammation in patients with COPD using fractional exhaled nitric oxide levels: a pilot study, Int. J. Chronic Obstr. Pulm. Dis. 9 (2014) 745.

[30] P.J. Castaldi, M. Benet, H. Petersen, et al., Do COPD subtypes really exist? COPD heterogeneity and clustering in 10 independent cohorts, Thorax 72 (11) (2017 Nov 1) 998-1006.

[31] Radin G, Duan F, Billatos E, Snyder B, Stevenson C, Gatsonis C, O’Connor GT, Lenburg M, Washko G, Spira A. Characterizing Clinical and Imaging Phenotypes of COPD within the Decamp Consortium. InC 22. COPD PHENOTYPES 2017 May (pp. A5002-A5002). American Thoracic Society.

[32] R. Vazquez Guillamet, O. Ursu, G. Iwamoto, P.L. Moseley, T. Oprea, Chronic obstructive pulmonary disease phenotypes using cluster analysis of electronic medical records, Health Inf. J. 24 (4) (2018 Dec) 394-409.

[33] R.F. Xavier, A.C. Pereira, A.C. Lopes, V. Cavalheri, R.M. Pinto, A. Cukier, E. M. Ramos, C.R. Carvalho, Identification of phenotypes in people with COPD: influence of physical activity, sedentary behaviour, body composition and skeletal muscle strength, Lung 197 (1) (2019 Feb 15) 37-45.

[34] J.P. de Torres, J.M. Marin, C. Martinez-Gonzalez, P. de Lucas-Ramos, B. Cosio, C. Casanova, COPD History Assessment in Spain (CHAIN) cohort. The importance of symptoms in the longitudinal variability of clusters in COPD patients: a validation study, Respirology 23 (5) (2018 May) 485-491.

[35] S. Zarei, A. Mirtar, J.D. Morrow, P.J. Castaldi, P. Belloni, C.P. Hersh, Subtyping chronic obstructive pulmonary disease using peripheral blood proteomics, Chronic Obstructive Pulmonary Diseases 4 (2) (2017) 97.

[36] M. Bafadhel, I. Umar, S. Gupta, J.V. Raj, D.D. Vara, J.J. Entwisle, I.D. Pavord, C. E. Brightling, S. Siddiqui, The role of CT scanning in multidimensional phenotyping of COPD, Chest 140 (3) (2011 Sep 1) 634-642.

[37] S. Lainez, I. Court-Fortune, P. Vercherin, L. Falchero, T. Didi, P. Beynel, D. Piperno, E. Frappe, M. Froudarakis, J.M. Vergnon, G. Devouassoux, Clinical ACO phenotypes: description of a heterogeneous entity, Respiratory medicine case reports 28 (2019 Jan 1) 100929.

[38] B. Haghighi, S. Choi, J. Choi, E.A. Hoffman, A.P. Comellas, J.D. Newell, C.H. Lee, R.G. Barr, E. Bleecker, C.B. Cooper, D. Couper, Imaging-based clusters in former smokers of the COPD cohort associate with clinical characteristics: the SubPopulations and intermediate outcome measures in COPD study (SPIROMICS), Respir. Res. 20 (1) (2019 Dec) 153.

[39] M. Karayama, N. Inui, H. Yasui, M. Kono, H. Hozumi, Y. Suzuki, K. Furuhashi, D. Hashimoto, N. Enomoto, T. Fujisawa, Y. Nakamura, Clinical features of threedimensional computed tomography-based radiologic phenotypes of chronic obstructive pulmonary disease, Int. J. Chronic Obstr. Pulm. Dis. 14 (2019) 1333.

[40] P. Ning, Y.F. Guo, T.Y. Sun, H.S. Zhang, D. Chai, X.M. Li, Study of the clinical phenotype of symptomatic chronic airways disease by hierarchical cluster analysis and two-step cluster analyses, Zhonghua nei ke za zhi 55 (9) (2016 Sep) 679-683. 
[41] G. Rootmensen, A. van Keimpema, A. Zwinderman, P. Sterk, Clinical phenotypes of obstructive airway diseases in an outpatient population, J. Asthma 53 (10) (2016 Nov 25) 1026-1032.

[42] N. Fens, A.G. van Rossum, P. Zanen, B. van Ginneken, R.J. van Klaveren, A. H. Zwinderman, P.J. Sterk, Subphenotypes of mild-to-moderate COPD by factor and cluster analysis of pulmonary function, CT imaging and breathomics in a population-based survey. COPD, Journal of Chronic Obstructive Pulmonary Disease 10 (3) (2013 Jun 1) 277-285.

[43] M. Bafadhel, S. McKenna, S. Terry, V. Mistry, C. Reid, P. Haldar, M. McCormick, K. Haldar, T. Kebadze, A. Duvoix, K. Lindblad, Acute exacerbations of chronic obstructive pulmonary disease: identification of biologic clusters and their biomarkers, Am. J. Respir. Crit. Care Med. 184 (6) (2011 Sep 15) 662-671.

[44] M.H. Cho, G.R. Washko, T.J. Hoffmann, G.J. Criner, E.A. Hoffman, F.J. Martinez N. Laird, J.J. Reilly, E.K. Silverman, Cluster analysis in severe emphysema subjects using phenotype and genotype data: an exploratory investigation, Respir. Res. 11 (1) (2010 Dec 1) 30.

[45] R.A. Incalzi, G.W. Canonica, N. Scichilone, S. Rizzoli, L. Simoni, F. Blasi, Storico study group, The COPD multi-dimensional phenotype: a new classification from the STORICO Italian observational study, PloS One 14 (9) (2019).

[46] C. Raherison, E.H. Ouaalaya, A. Bernady, J. Casteigt, C. Nocent-Eijnani, L. Falque, F. Le Guillou, L. Nguyen, A. Ozier, M. Molimard, Comorbidities and COPD severity in a clinic-based cohort, BMC Pulm. Med. 18 (1) (2018 Dec 1) 117.

[47] R. de Vries, Y.W. Dagelet, P. Spoor, E. Snoey, P.M. Jak, P. Brinkman, E. Dijkers, S K. Bootsma, F. Elskamp, F.H. De Jongh, E.G. Haarman, Clinical and inflammatory phenotyping by breathomics in chronic airway diseases irrespective of the diagnostic label, Eur. Respir. J. 51 (1) (2018 Jan 1).

[48] J. Fingleton, K. Huang, M. Weatherall, Y. Guo, S. Ivanov, P. Bruijnzeel, H. Zhang, W. Wang, R. Beasley, C. Wang, Phenotypes of symptomatic airways disease in China and New Zealand, Eur. Respir. J. 50 (6) (2017 Dec 1) 1700957.

[49] J.H. Lee, C.K. Rhee, K. Kim, J.A. Kim, S.H. Kim, K.H. Yoo, W.J. Kim, Y.B. Park, H. Y. Park, K.S. Jung, Identification of subtypes in subjects with mild-to-moderate airflow limitation and its clinical and socioeconomic implications, Int. J. Chronic Obstr. Pulm. Dis. 12 (2017) 1135.

[50] K. Sekiya, E. Nakatani, Y. Fukutomi, H. Kaneda, M. Iikura, M. Yoshida, K. Takahashi, K. Tomii, M. Nishikawa, N. Kaneko, Y. Sugino, Severe or lifethreatening asthma exacerbation: patient heterogeneity identified by cluster analysis, Clin. Exp. Allergy 46 (8) (2016 Aug) 1043-1055.

[51] M. Weatherall, J. Travers, P.M. Shirtcliffe, S.E. Marsh, M.V. Williams, M. R. Nowitz, S. Aldington, R. Beasley, Distinct clinical phenotypes of airways disease defined by cluster analysis, Eur. Respir. J. 34 (4) (2009 Oct 1) 812-818.

[52] V. Nikolaou, Statistical analysis: a practical guide for psychiatrists, BJPsych Adv. 22 (4) (2016 Jul) 251-259.

[53] Y. Mori, M. Kuroda, N. Makino, Nonlinear principal component analysis, in: Nonlinear Principal Component Analysis and its Applications, Springer, Singapore, 2016, pp. 7-20.

[54] D.N. Lawley, A.E. Maxwell, Regression and factor analysis, Biometrika 60 (2) (1973 Aug 1) 331-338.

[55] K.G. Joereskog, Statistical Estimation in Factor Analysis, Almqvist \& Wiksell, 1963.

[56] F. Murtagh, P. Legendre, Ward's hierarchical agglomerative clustering method: which algorithms implement Ward's criterion? J. Classif. 31 (3) (2014 Oct 1) 274-295.

[57] X. Basagaña, J. Barrera-Gómez, M. Benet, J.M. Antó, J. Garcia-Aymerich, A framework for multiple imputation in cluster analysis, Am. J. Epidemiol. 177 (7) (2013 Apr 1) 718-725.

[58] J. Bourbeau, L.M. Pinto, A. Benedetti, Phenotyping of COPD: challenges and next steps, The Lancet Respiratory Medicine 2 (3) (2014 Mar 1) 172-174.

[59] Biobank Uk. https://www.ukbiobank.ac.uk/(accessed Aug 15, 2019).

[60] S. Pascoe, N. Barnes, G. Brusselle, C. Compton, G.J. Criner, M.T. Dransfield, D. M. Halpin, M.K. Han, B. Hartley, P. Lange, S. Lettis, Blood eosinophils and treatment response with triple and dual combination therapy in chronic obstructive pulmonary disease: analysis of the IMPACT trial, The Lancet Respiratory Medicine 7 (9) (2019 Sep 1) 745-756.

[61] P. Sivapalan, T.S. Lapperre, J. Janner, R.R. Laub, M. Moberg, C.S. Bech, J. Eklöf, F.S. Holm, K. Armbruster, P. Sivapalan, C. Mosbech, Eosinophil-guided corticosteroid therapy in patients admitted to hospital with COPD exacerbation (CORTICO-COP): a multicentre, randomised, controlled, open-label, noninferiority trial, The Lancet Respiratory Medicine 7 (8) (2019 Aug 1) 699-709.

[62] W.H. van Geffen, D.J. Slebos, F.J. Herth, S.V. Kemp, W. Weder, P.L. Shah, Surgical and endoscopic interventions that reduce lung volume for emphysema: a systemic review and meta-analysis, The Lancet Respiratory Medicine 7 (4) (2019 Apr 1) 313-324.

[63] P. Sun, R. Ye, C. Wang, S. Bai, L. Zhao, Identification of proteomic signatures associated with COPD frequent exacerbators, Life Sci. 230 (2019 Aug 1) 1-9.

[64] A. Pichl, N. Sommer, M. Bednorz, M. Seimetz, S. Hadzic, S. Kuhnert, S. Kraut, E. T. Roxlau, B. Kojonazarov, J. Wilhelm, M. Gredic, Riociguat for treatment of pulmonary hypertension in COPD: a translational study, Eur. Respir. J. 53 (6) (2019 Jun 1) 1802445.

[65] A.A. Pragman, K.A. Knutson, T.J. Gould, R.E. Isaacson, C.S. Reilly, C.H. Wendt, Chronic obstructive pulmonary disease upper airway microbiota alpha diversity is associated with exacerbation phenotype: a case-control observational study, Respir. Res. 20 (1) (2019 Dec 1) 114.

[66] L.V. Kukol, S.A. Pupyshev, Determination of phenotypic characteristics of chronic obstructive lung disease in elderly patients, Advances in gerontology= Uspekhi gerontologii 32 (3) (2019) 445-450.
[67] A.A. Pragman, K.A. Knutson, T.J. Gould, S.W. Hodgson, R.E. Isaacson, C.S. Reilly, C.H. Wendt, Chronic obstructive pulmonary disease upper airway microbiome is associated with select clinical characteristics, PloS One 14 (7) (2019).

[68] S.H. Bak, H.Y. Park, J.H. Nam, H.Y. Lee, J.H. Lee, I. Sohn, M.P. Chung, Predicting clinical outcome with phenotypic clusters using quantitative CT fibrosis and emphysema features in patients with idiopathic pulmonary fibrosis, PloS One 14 (4) (2019).

[69] A.E. Kneppers, R.A. Haast, R.C. Langen, L.B. Verdijk, P.A. Leermakers, H. R. Gosker, L.J. van Loon, M. Lainscak, A.M. Schols, Distinct skeletal muscle molecular responses to pulmonary rehabilitation in chronic obstructive pulmonary disease: a cluster analysis, Journal of cachexia, sarcopenia and muscle 10 (2) (2019 Apr) 311-322.

[70] A. Gedebjerg, S.K. Szépligeti, L.M. Wackerhausen, E. Horváth-Puhó, R. Dahl, J. G. Hansen, H.T. Sørensen, M. Nørgaard, P. Lange, R.W. Thomsen, Prediction of mortality in patients with chronic obstructive pulmonary disease with the new Global Initiative for Chronic Obstructive Lung Disease 2017 classification: a cohort study, The Lancet Respiratory Medicine 6 (3) (2018 Mar 1) 204-212.

[71] M. Merrill, C. Roeder, M. Butler, B. Doran, L. Stevens, C. Goerg, D. Kao, Complex heart failure phenotypes differ in response to medical therapy and exercise training, Circulation 138 (Suppl_1) (2018 Nov 6) A16910.

[72] El Boueiz AR, Chang Y, Cho MH, DeMeo DL, Dy J, Silverman EK, Castaldi P. Machine learning prediction of 5-year progression of FEV1 in the COPDGene study. InD 101. MECHANISTIC and TRANSLATIONAL STUDIES IN COPD 2018 May (pp. A7430-A7430). American Thoracic Society.

[73] L. Fang, P. Gao, H. Bao, X. Tang, B. Wang, Y. Feng, S. Cong, J. Juan, J. Fan, K. Lu, N. Wang, Chronic obstructive pulmonary disease in China: a nationwide prevalence study, The Lancet Respiratory Medicine 6 (6) (2018 Jun 1) 421-430.

[74] H.K. Koo, D.M. Vasilescu, S. Booth, A. Hsieh, O.L. Katsamenis, N. Fishbane, W. M. Elliott, M. Kirby, P. Lackie, I. Sinclair, J.A. Warner, Small airways disease in mild and moderate chronic obstructive pulmonary disease: a cross-sectional study, The Lancet Respiratory Medicine 6 (8) (2018 Aug 1) 591-602.

[75] X. Liang, Q. Sha, Y. Rho, S. Zhang, A hierarchical clustering method for dimension reduction in joint analysis of multiple phenotypes, Genet. Epidemiol. 42 (4) (2018 Jun) 344-353.

[76] K. Kilk, A. Aug, A. Ottas, U. Soomets, S. Altraja, A. Altraja, Phenotyping of chronic obstructive pulmonary disease based on the integration of metabolomes and clinical characteristics, Int. J. Mol. Sci. 19 (3) (2018 Mar) 666.

[77] O. Le Rouzic, N. Roche, A.B. Cortot, I. Tillie-Leblond, F. Masure, T. Perez, I. Boucot, L. Hamouti, J. Ostinelli, C. Pribil, C. Poutchnine, Defining the "frequent exacerbator" phenotype in COPD: a hypothesis-free approach, Chest 153 (5) (2018 May 1) 1106-1115.

[78] M. Hall, T.B. Dondo, A.T. Yan, M.A. Mamas, A.D. Timmis, J.E. Deanfield, T. Jernberg, H. Hemingway, K.A. Fox, C.P. Gale, Multimorbidity and survival for patients with acute myocardial infarction in England and Wales: latent class analysis of a nationwide population-based cohort, PLoS Med. 15 (3) (2018 Mar).

[79] N. Das, M. Topalovic, W. Janssens, Artificial intelligence in diagnosis of obstructive lung disease: current status and future potential, Curr. Opin. Pulm. Med. 24 (2) (2018 Mar 1) 117-123.

[80] R. Merchant, S.J. Szefler, B.G. Bender, M. Tuffli, M.A. Barrett, R. Gondalia, L. Kaye, D. Van Sickle, D.A. Stempel, Impact of a digital health intervention on asthma resource utilization, World Allergy Organization Journal 11 (1) (2018 Dec 1) 28.

[81] Christenson S, Bolourchi S, Huffnagle G, Erb-Downward J, Hanauer G, Saetta M, Rabe K, Martinez FJ, Woodruff PG. Molecular Phenotyping of Chronic Bronchitis: Mucin and Inflammatory Gene Expression Heterogeneity in COPD.

[82] M. Kästle, S. Bartel, K. Geillinger-Kästle, M. Irmler, J. Beckers, B. Ryffel, O. Eickelberg, S. Krauss-Etschmann, Micro RNA cluster $106 a \tilde{~} 363$ is involved in T helper 17 cell differentiation, Immunology 152 (3) (2017 Nov) 402-413.

[83] M.A. Fouda, E.H. Alhamad, M.S. Al-Hajjaj, S.A. Shaik, A.A. Alboukai, F.A. AlKassimi, A study of chronic obstructive pulmonary disease-specific causes of osteoporosis with emphasis on the emphysema phenotype, Ann. Thorac. Med. 12 (2) (2017 Apr) 101

[84] J.D. Chalmers, Bronchiectasis: phenotyping a complex disease, COPD 14 (sup1) (2017 Mar 15) S12-S18.

[85] K. Hirai, T. Shirai, M. Suzuki, T. Akamatsu, T. Suzuki, I. Hayashi, A. Yamamoto, T. Akita, S. Morita, K. Asada, D. Tsuji, A clustering approach to identify and characterize the asthma and chronic obstructive pulmonary disease overlap phenotype, Clin. Exp. Allergy 47 (11) (2017 Nov) 1374-1382.

[86] K. Haldar, M. Bafadhel, K. Lau, A. Berg, B. Kwambana, T. Kebadze, M. Y. Ramsheh, B. Barker, P. Haldar, S. Johnston, J.M. Ketley, Microbiome balance in sputum determined by PCR stratifies COPD exacerbations and shows potential for selective use of antibiotics, PloS One 12 (8) (2017).

[87] Y. Çolak, S. Afzal, B.G. Nordestgaard, J. Vestbo, P. Lange, Prognosis of asymptomatic and symptomatic, undiagnosed COPD in the general population in Denmark: a prospective cohort study, The Lancet Respiratory Medicine 5 (5) (2017 May 1) 426-434.

[88] M. Maddocks, C.M. Nolan, W.D. Man, M.I. Polkey, N. Hart, W. Gao, G.F. Rafferty, J. Moxham, I.J. Higginson, Neuromuscular electrical stimulation to improve exercise capacity in patients with severe COPD: a randomised double-blind, placebo-controlled trial, The Lancet Respiratory Medicine 4 (1) (2016 Jan 1) 27-36.

[89] P. Lange, Y. Çolak, T.S. Ingebrigtsen, J. Vestbo, J.L. Marott, Long-term prognosis of asthma, chronic obstructive pulmonary disease, and asthma-chronic obstructive pulmonary disease overlap in the Copenhagen City Heart study: a prospective population-based analysis, The Lancet Respiratory Medicine 4 (6) (2016 Jun 1) 454-462. 
[90] S. Sato, Y. Tanino, K. Misa, N. Fukuhara, T. Nikaido, M. Uematsu, A. Fukuhara, X. Wang, T. Ishida, M. Munakata, Identification of clinical phenotypes in idiopathic interstitial pneumonia with pulmonary emphysema, Intern. Med. 55 (12) (2016 Jun 15) 1529-1535.

[91] C. Morélot-Panzini, H. Gilet, B. Aguilaniu, P. Devillier, A. Didier, T. Perez, C. Pignier, B. Arnould, T. Similowski, Real-life assessment of the multidimensional nature of dyspnoea in COPD outpatients, Eur. Respir. J. 47 (6) (2016 Jun 1) 1668-1679.

[92] O. Roche, M.L. Deguiz, M. Tiana, C. Galiana-Ribote, D. Martinez-Alcazar, C. ReySerra, B. Ranz-Ribeiro, R. Casitas, R. Galera, I. Fernández-Navarro, S. SánchezCuéllar, Identification of non-coding genetic variants in samples from hypoxemic respiratory disease patients that affect the transcriptional response to hypoxia, Nucleic Acids Res. 44 (19) (2016 Nov 2) 9315-9330.

[93] M.Á. Martínez-García, M. Vendrell, R. Girón, L. Máiz-Carro, D. de la Rosa Carrillo, J. de Gracia, C. Olveira, The multiple faces of non-cystic fibrosis bronchiectasis. A cluster Analysis approach, Annals of the American Thoracic Society 13 (9) (2016 Sep) 1468-1475.

[94] R. Batista-Navarro, J. Carter, S. Ananiadou, Argo: enabling the development of bespoke workflows and services for disease annotation, Database 2016 (2016 Jan 1).

[95] C.J. Labuzzetta, M.L. Antonio, P.M. Watson, R.C. Wilson, L.A. Laboissonniere, J, M. Trimarchi, B. Genc, P.H. Ozdinler, D.K. Watson, P.E. Anderson, Complementary feature selection from alternative splicing events and gene expression for phenotype prediction, Bioinformatics 32 (17) (2016 Sep 1) i421-i429.

[96] M.R. Kaluarachchi, C.L. Boulangé, I. Garcia-Perez, J.C. Lindon, E.F. Minet, Multiplatform serum metabolic phenotyping combined with pathway mapping to identify biochemical differences in smokers, Bioanalysis 8 (19) (2016 Oct) 2023-2043.

[97] M.E. Obeidat, K. Hao, Y. Bossé, D.C. Nickle, Y. Nie, D.S. Postma, M. Laviolette, A J. Sandford, D.D. Daley, J.C. Hogg, W.M. Elliott, Molecular mechanisms underlying variations in lung function: a systems genetics analysis, The Lancet Respiratory Medicine 3 (10) (2015 Oct 1) 782-795.

[98] S. Kim, J.D. Herazo-Maya, D.D. Kang, B.M. Juan-Guardela, J. Tedrow, F. J. Martinez, F.C. Sciurba, G.C. Tseng, N. Kaminski, Integrative phenotyping framework (iPF): integrative clustering of multiple omics data identifies nove lung disease subphenotypes, BMC Genom. 16 (1) (2015 Dec 1) 924.

[99] M. Huebenthal, G. Hemmrich-Stanisak, F. Degenhardt, S. Szymczak, Z. Du, A. Elsharawy, A. Keller, S. Schreiber, A. Franke, Sparse modeling reveals miRNA signatures for diagnostics of inflammatory bowel disease, PloS One 10 (10) (2015).

[100] J.H. Lee, M.H. Cho, M.L. McDonald, C.P. Hersh, P.J. Castaldi, J.D. Crapo, E. S. Wan, J.G. Dy, Y. Chang, E.A. Regan, M. Hardin, Phenotypic and genetic heterogeneity among subjects with mild airflow obstruction in COPDGene, Respir. Med. 108 (10) (2014 Oct 1) 1469-1480.

[101] S. Uzun, R.S. Djamin, J.A. Kluytmans, P.G. Mulder, N.E. van’t Veer, A.A. Ermens, A.J. Pelle, H.C. Hoogsteden, J.G. Aerts, M.M. van der Eerden, Azithromycin maintenance treatment in patients with frequent exacerbations of chronic obstructive pulmonary disease (COLUMBUS): a randomised, double-blind, placebo-controlled trial, The Lancet Respiratory Medicine 2 (5) (2014 May 1) $361-368$.

[102] C.E. Brightling, E.R. Bleecker, R.A. Panettieri Jr., M. Bafadhel, D. She, C.K. Ward, X. Xu, C. Birrell, R. van der Merwe, Benralizumab for chronic obstructive pulmonary disease and sputum eosinophilia: a randomised, double-blind, placebo-controlled, phase 2a study, The Lancet Respiratory Medicine 2 (11) (2014 Nov 1) 891-901.

[103] S.S. Kon, J.L. Canavan, S.E. Jones, C.M. Nolan, A.L. Clark, M.J. Dickson, B. M. Haselden, M.I. Polkey, W.D. Man, Minimum clinically important difference for the COPD Assessment Test: a prospective analysis, The Lancet Respiratory Medicine 2 (3) (2014 Mar 1) 195-203.

[104] T. Köhnlein, W. Windisch, D. Köhler, A. Drabik, J. Geiseler, S. Hartl, O. Karg, G. Laier-Groeneveld, S. Nava, B. Schönhofer, B. Schucher, Non-invasive positive pressure ventilation for the treatment of severe stable chronic obstructive pulmonary disease: a prospective, multicentre, randomised, controlled clinical trial, The Lancet Respiratory Medicine 2 (9) (2014 Sep 1) 698-705.

[105] R.C. Jones, D. Price, D. Ryan, E.J. Sims, J. von Ziegenweidt, L. Mascarenhas, A. Burden, D.M. Halpin, R. Winter, S. Hill, M. Kearney, Opportunities to diagnose chronic obstructive pulmonary disease in routine care in the UK: a retrospective study of a clinical cohort, The Lancet Respiratory Medicine 2 (4) (2014 Apr 1) 267-276.

[106] J.P. Zheng, F.Q. Wen, C.X. Bai, H.Y. Wan, J. Kang, P. Chen, W.Z. Yao, L.J. Ma, X. Li, L. Raiteri, M. Sardina, Twice daily N-acetylcysteine $600 \mathrm{mg}$ for exacerbations of chronic obstructive pulmonary disease (PANTHEON): a randomised, double-blind placebo-controlled trial, The Lancet Respiratory Medicine 2 (3) (2014 Mar 1) 187-194.

[107] J.L. Corhay, F. Schleich, R. Louis, Phenotypes in chronic obstructive pulmonary disease, Rev. Med. Liege 69 (7-8) (2014) 415-421.

[108] W.C. Moore, A.T. Hastie, X. Li, H. Li, W.W. Busse, N.N. Jarjour, S.E. Wenzel, S. P. Peters, D.A. Meyers, E.R. Bleecker, N. Heart, Sputum neutrophil counts are associated with more severe asthma phenotypes using cluster analysis, J. Allergy Clin. Immunol. 133 (6) (2014 Jun 1) 1557-1563.

[109] D. Qiao, M.H. Cho, H. Fier, P.S. Bakke, A. Gulsvik, E.K. Silverman, C. Lange, On the simultaneous association analysis of large genomic regions: a massive multilocus association test, Bioinformatics 30 (2) (2014 Jan 15) 157-164.

[110] R.L. DiSantostefano, H. Li, D. Hinds, D.V. Galkin, D.B. Rubin, Risk of pneumonia with inhaled corticosteroid/long-acting $\beta 2$ agonist therapy in chronic obstructive pulmonary disease: a cluster analysis, Int. J. Chronic Obstr. Pulm. Dis. 9 (2014) 457.

[111] C.F. Vogelmeier, E.D. Bateman, J. Pallante, V.K. Alagappan, P. D’Andrea, H. Chen, D. Banerji, Efficacy and safety of once-daily QVA149 compared with twice-daily salmeterol-fluticasone in patients with chronic obstructive pulmonary disease (ILLUMINATE): a randomised, double-blind, parallel group study, The Lancet Respiratory Medicine 1 (1) (2013 Mar 1) 51-60.

[112] L.G. Franciosi, Z. Diamant, K.H. Banner, R. Zuiker, N. Morelli, I.M. Kamerling, M. L. de Kam, J. Burggraaf, A.F. Cohen, M. Cazzola, L. Calzetta, Efficacy and safety of RPL554, a dual PDE3 and PDE4 inhibitor, in healthy volunteers and in patients with asthma or chronic obstructive pulmonary disease: findings from four clinical trials, The lancet Respiratory medicine 1 (9) (2013 Nov 1) 714-727.

[113] M.L. Decramer, K.R. Chapman, R. Dahl, P. Frith, G. Devouassoux, C. Fritscher, R. Cameron, M. Shoaib, D. Lawrence, D. Young, D. McBryan, Once-daily indacaterol versus tiotropium for patients with severe chronic obstructive pulmonary disease (INVIGORATE): a randomised, blinded, parallel-group study, The Lancet Respiratory medicine 1 (7) (2013 Sep 1) 524-533.

[114] M.T. Dransfield, J. Bourbeau, P.W. Jones, N.A. Hanania, D.A. Mahler, J. Vestbo, A. Wachtel, F.J. Martinez, F. Barnhart, L. Sanford, S. Lettis, Once-daily inhaled fluticasone furoate and vilanterol versus vilanterol only for prevention of exacerbations of COPD: two replicate double-blind, parallel-group, randomised controlled trials, The Lancet Respiratory Medicine 1 (3) (2013 May 1) 210-223.

[115] J.A. Wedzicha, M. Decramer, J.H. Ficker, D.E. Niewoehner, T. Sandström, A. F. Taylor, P. D'Andrea, C. Arrasate, H. Chen, D. Banerji, Analysis of chronic obstructive pulmonary disease exacerbations with the dual bronchodilator QVA149 compared with glycopyrronium and tiotropium (SPARK): a randomised, double-blind, parallel-group study, The lancet Respiratory medicine 1 (3) (2013 May 1) 199-209.

[116] K.F. Rabe, L.M. Fabbri, E. Israel, H. Kögler, K. Riemann, H. Schmidt, T. Glaab, C. F. Vogelmeier, Effect of ADRB2 polymorphisms on the efficacy of salmeterol and tiotropium in preventing COPD exacerbations: a prespecified substudy of the POET-COPD trial, The Lancet Respiratory Medicine 2 (1) (2014 Jan 1) 44-53.

[117] M. Siedlinski, D. Tingley, P.J. Lipman, M.H. Cho, A.A. Litonjua, D. Sparrow, P. Bakke, A. Gulsvik, D.A. Lomas, W. Anderson, X. Kong, Dissecting direct and indirect genetic effects on chronic obstructive pulmonary disease (COPD) susceptibility, Hum. Genet. 132 (4) (2013 Apr 1) 431-441.

[118] F. Gouzi, A. Abdellaoui, N. Molinari, E. Pinot, B. Ayoub, D. Laoudj-Chenivesse, J. P. Cristol, J. Mercier, M. Hayot, C. Préfaut, Fiber atrophy, oxidative stress, and oxidative fiber reduction are the attributes of different phenotypes in chronic obstructive pulmonary disease patients, J. Appl. Physiol. 115 (12) (2013 Dec 15) 1796-1805.

[119] R. Shaykhiev, R. Sackrowitz, T. Fukui, W.L. Zuo, I.W. Chao, Y. Strulovici-Barel, R. J. Downey, R.G. Crystal, Smoking-induced CXCL14 expression in the human airway epithelium links chronic obstructive pulmonary disease to lung cancer, Am. J. Respir. Cell Mol. Biol. 49 (3) (2013 Sep) 418-425.

[120] B.J. Carolan, E.R. Sutherland, Clinical phenotypes of chronic obstructive pulmonary disease and asthma: recent advances, J. Allergy Clin. Immunol. 131 (3) (2013 Mar 1) 627-634.

[121] D.M. Toraldo, M. Minelli, F. De Nuccio, G. Nicolardi, Chronic obstructive pulmonary disease phenotype desaturator with hypoxic vascular remodelling and pulmonary hypertension obtained by cluster analysis, Multidisciplinary respiratory medicine 7 (1) (2012 Dec) 39.

[122] J. Travers, M. Weatherall, J. Fingleton, R. Beasley, Towards individualised medicine for airways disease: identifying clinical phenotype groups, Eur. Respir. J. 39 (4) (2012 Apr 1) 1033-1034.

[123] D.M. Toraldo, F. De Nuccio, A. Gaballo, G. Nicolardi, Use of cluster analysis to describe desaturator phenotypes in COPD: correlations between pulmonary function tests and nocturnal oxygen desaturation, Int. J. Chronic Obstr. Pulm. Dis. 6 (2011) 551.

[124] Fingleton J, Weatherall M, Beasley R. Towards Individualised Treatment in COPD.

[125] P. Shirtcliffe, M. Weatherall, J. Travers, R. Beasley, The multiple dimensions of airways disease: targeting treatment to clinical phenotypes, Curr. Opin. Pulm. Med. 17 (2) (2011 Mar 1) 72-78.

[126] Sharma S, Miller DP, Emmett A, Li H. Cluster Analysis for the identification and replication of distinct subject clusters from COPD clinical trials. InA 41. CHRONIC OBSTRUCTIVE PULMONARY DISEASE EXACERBATIONS: EPIDEMIOLOGY and OUTCOMES 2010 May (pp. A1501-A1501). American Thoracic Society.

[127] K.W. Jo, S.W. Ra, E.J. Chae, J.B. Seo, N.K. Kim, J.H. Lee, E.K. Kim, Y.K. Lee, T. H. Kim, J.W. Huh, W.J. Kim, Three phenotypes of obstructive lung disease in the elderly, Int. J. Tubercul. Lung Dis. 14 (11) (2010 Nov 1) 1481-1488.

[128] P. Sobradillo, J. Garcia-Aymerich, A. Agusti, Clinical phenotypes of COPD, Arch. Bronconeumol. 46 (2010 Dec) 8-11. 
[129] M. Weatherall, P. Shirtcliffe, J. Travers, R. Beasley, Use of cluster analysis to define COPD phenotypes, Eur. Respir. J. 36 (3) (2010 Sep 1) 472-474.

[130] M. Paoletti, G. Camiciottoli, E. Meoni, F. Bigazzi, L. Cestelli, M. Pistolesi, C. Marchesi, Explorative data analysis techniques and unsupervised clustering methods to support clinical assessment of Chronic Obstructive Pulmonary Disease (COPD) phenotypes, J. Biomed. Inf. 42 (6) (2009 Dec 1) 1013-1021.

[131] M. Pistolesi, G. Camiciottoli, M. Paoletti, C. Marmai, F. Lavorini, E. Meoni, C. Marchesi, C. Giuntini, Identification of a predominant COPD phenotype in clinical practice, Respir. Med. 102 (3) (2008 Mar 1) 367-376.

[132] B.D. Patel, H.O. Coxson, S.G. Pillai, A.G. Agusti, P.M. Calverley, C.F. Donner, B. J. Make, N.L. Muller, S.I. Rennard, J. Vestbo, E.F. Wouters, Airway wall thickening and emphysema show independent familial aggregation in chronic obstructive pulmonary disease, Am. J. Respir. Crit. Care Med. 178 (5) (2008 Sep 1) $500-505$.

[133] Kodavanti Up, M.C. Schladweiler, A.D. Ledbetter, R.V. Ortuno, M. Suffia, P. Evansky, J.H. Richards, R.H. Jaskot, R. Thomas, E. Karoly, Y.C. Huang, The spontaneously hypertensive rat: an experimental model of sulfur dioxide-induced airways disease, Toxicol. Sci. 94 (1) (2006 Nov 1) 193-205.

[134] A.J. Wardlaw, M. Silverman, R. Siva, I.D. Pavord, R. Green, Multi-dimensional phenotyping: towards a new taxonomy for airway disease, Clin. Exp. Allergy 35 (10) (2005 Oct) 1254-1262.

[135] N.R. Hackett, A. Heguy, B.G. Harvey, T.P. O'Connor, K. Luettich, D.B. Flieder, R. Kaplan, R.G. Crystal, Variability of antioxidant-related gene expression in the airway epithelium of cigarette smokers, Am. J. Respir. Cell Mol. Biol. 29 (3) (2003 Sep) $331-343$. 